\title{
Dynamic and timing properties of new aerosol particle formation and consecutive growth events
}

\author{
Imre Salma and Zoltán Németh \\ Institute of Chemistry, Eötvös University, 1518 Budapest, P.O. Box 32, Hungary \\ Correspondence: Imre Salma (salma@ chem.elte.hu)
}

Received: 2 September 2018 - Discussion started: 1 October 2018

Revised: 1 April 2019 - Accepted: 22 April 2019 - Published: 3 May 2019

\begin{abstract}
Dynamic properties, i.e. particle formation rate $J_{6}$ and particle diameter growth rate $\mathrm{GR}_{10}$, and timing properties, i.e. starting time $\left(t_{1}\right)$ and duration time interval $(\Delta t)$ of 247 quantifiable atmospheric new aerosol particle formation (NPF) and growth events identified in the city centre and near-city background of Budapest over 6 full measurement years, together with related gas-phase $\mathrm{H}_{2} \mathrm{SO}_{4}$ proxy, condensation sink (CS) of vapours, basic meteorological data and concentrations of criteria pollutant gases were derived, evaluated, discussed and interpreted. In the city centre, nucleation ordinarily starts at $09: 15 \mathrm{UTC}+1$, and it is maintained for approximately $3 \mathrm{~h}$. The NPF and growth events produce 4.6 aerosol particles with a diameter of $6 \mathrm{~nm}$ in $1 \mathrm{~cm}^{3}$ of air in $1 \mathrm{~s}$ and cause the particles with a diameter of $10 \mathrm{~nm}$ to grow at a typical rate of $7.3 \mathrm{~nm} \mathrm{~h}^{-1}$. Nucleation starts approximately $1 \mathrm{~h}$ earlier in the near-city background, and it shows substantially smaller $J_{6}$ (with a median of $2.0 \mathrm{~cm}^{-3} \mathrm{~s}^{-1}$ ) and $\mathrm{GR}_{10}$ values (with a median of $5.0 \mathrm{~nm} \mathrm{~h}^{-1}$ ), while the duration of nucleation is similar to that in the centre. Monthly distributions of the dynamic properties and daily maximum $\mathrm{H}_{2} \mathrm{SO}_{4}$ proxy do not follow the mean monthly pattern of the event occurrence frequency. The factors that control the event occurrence and that govern the intensity of particle formation and growth are not directly linked. New particle formation and growth processes advance in a different manner in the city and its close environment. This could likely be related to diversities in atmospheric composition, chemistry and physics. Monthly distributions and relationships among the properties mentioned provided indirect evidence that chemical species other than $\mathrm{H}_{2} \mathrm{SO}_{4}$ largely influence the particle growth and possibly atmospheric NPF process as well. The $J_{6}, \mathrm{GR}_{10}$ and $\Delta t$ can be described by a lognormal distribution function. Most extreme dynamic proper-
\end{abstract}

ties could not be explained by available single or compound variables. Approximately $40 \%$ of the NPF and growth events exhibited broad beginning, which can be an urban feature. For doublets, the later onset frequently shows more intensive particle formation and growth than the first onset by a typical factor of approximately 1.5. The first event is attributed to a regional type, while the second event, superimposed on the first, is often associated with subregional, thus urban NPF and growth processes.

\section{Introduction}

Molecules and molecular fragments in the air collide randomly and can form electrically neutral or charged clusters. Most clusters decompose shortly. Chemical stabilizing interactions among certain components within a cluster can enhance its lifetime, during which it can grow further by additional molecular collisions through some distinguishable size regimes (Kulmala et al., 2014). If the diameter of these clusters reaches a critical value of $1.5 \pm 0.3 \mathrm{~nm}$ (Kulmala et al., 2013), they become thermodynamically stable, and their further growth turns into a spontaneous process. Supersaturation is a necessary atmospheric condition for this principal transformation. It is essentially a phase transition, which takes place in a dispersed manner in the atmosphere, so it generates an aerosol system. The newly formed particles grow further by condensation to larger sizes in most cases due to the existing supersaturation. Photochemical oxidation products such as $\mathrm{H}_{2} \mathrm{SO}_{4}$ (Sipilä et al., 2010), extremely low-volatile organic compounds (ELVOCs; Ehn et al., 2014; Jokinen et al., 2015) and highly oxygenated molecules (HOMs; Bianchi et al., 2016; Kirkby et al., 2016; Tröstl et al., 2016), together with 
$\mathrm{H}_{2} \mathrm{O}$ vapour, $\mathrm{NH}_{3}$ (Kirkby et al., 2011), amines (Almeida et al., 2013), other oxidation products of volatile organic compounds (VOCs; Metzger et al., 2010; Schobesberger et al., 2013; Riccobono et al., 2014) and some inhibiting chemical species (e.g. isoprene or $\mathrm{NO}_{2}$; Kiendler-Scharr et al., 2009; Kerminen et al., 2018), can play an important role in particle formation and growth. The VOCs include compounds of both anthropogenic and biogenic origin, mainly isoprenoids such as $\alpha$-pinene (Kirkby et al., 2016). In some specific coastal regions, iodine oxides produced from marine biota are involved (O'Dowd et al., 2002). Atmospheric concentration of these key compounds at a level that is smaller by $12-14$ orders of magnitude than the concentration of air molecules is already sufficient for the phenomenon (Kulmala et al., 2014). Relative importance of the organics increases with particle size (Riipinen et al., 2011; Ehn et al., 2014), and their supersaturation is maintained by fast gas-phase autooxidation reactions of VOCs (Crounse et al., 2013). The overall phenomenon is ordinarily confined in time for $1 \mathrm{~d}$ or so, and, therefore, it can be regarded as an event in time and is referred to as a new aerosol particle formation (NPF) and consecutive particle diameter growth event.

Such events appear to take place almost everywhere in the world and anytime (Kulmala et al., 2004; Kerminen et al., 2018; Nieminen et al., 2018). Their occurrence frequency and, more importantly, their contribution to particle number concentrations were found to be substantial or determinant in the global troposphere (Spracklen et al., 2006; Kulmala et al., 2014). Moreover, their contribution to the number of cloud condensation nuclei $(\mathrm{CCN})$ can be $50 \%$ or even more (Makkonen et al., 2009; Merikanto et al., 2009; Sihto et al., 2011), which links the events to the climate system and emphasizes their global relevance (Kerminen et al., 2012; Makkonen et al., 2012; Carslaw et al., 2013; Gordon et al., 2016). New particle formation and growth events were proved to be common in polluted air of large cities as well, with a typical relative occurrence frequency between $10 \%$ and $30 \%$ (Woo et al., 2001; Baltensperger et al., 2002; Alam et al., 2003; Wehner et al., 2004; Salma et al., 2011; Dall'Osto et al., 2013; Xiao et al., 2015; Zhang et al., 2015; Kulmala et al., 2017, Nieminen et al., 2018). The coupling and relationships between regional and urban (subregional) NPF were demonstrated at least under favourable orographic conditions (Salma et al., 2016b). New particle formation can increase the existing particle number concentrations in city centres by a factor of approximately 2 on nucleation days, while it can produce $13 \%-28 \%$ of ultrafine (UF) particles as a lower estimate on a longer (e.g. annual) timescale (Salma et al., 2017). Particle concentrations from NPF are also important when compared to (primary) particles emitted by their dominant source in cities, namely by road vehicles with internal combustion engines (Paasonen et al., 2016). These results jointly suggest that particles from NPF and growth events in cities can influence not only the urban climate but can contribute to the public's excess health risk from particle number exposures (Oberdörster et al., 2005; Braakhuis et al., 2014; Salma et al., 2015) and, furthermore, could be linked to the role of human actions in all these effects.

Despite these potential points, conclusive interpretation of the data obtained and results derived specifically for cities have remained hindered so far. Several-year-long, semicontinuous, critically evaluated, complex and coherent data sets are required for this purpose, which have been generating gradually. As part of this international progress, investigations dedicated to urban NPF and growth events in Budapest have been going on since November 2008. Measurements for 5 full years were realized in the city centre at a fixed location, 1 full year was devoted to measurements in a near-city background environment, and some other measurements were accomplished in different urban microenvironments for time intervals of a few months. The main objectives of this study are to determine, present and analyse the dynamic properties, i.e. particle formation rate and particle diameter growth rate, timing properties, i.e. starting time and duration time interval of nucleation process of NPF and growth events, together with the major sources and sink of condensing vapours, basic meteorological data and criteria pollutant gases for 6 years, to investigate and interpret their relationships, to discuss their monthly distributions, to evaluate and detect some of their features specific for urban atmospheric environments and to demonstrate some specific urban influence on the calculation of the properties. These quantities and relationships are of basic importance in many atmospheric processes for several reasons. Our goals are in line with the research needs for global atmospheric nucleation studies (Kerminen et al., 2018; Nieminen et al., 2018).

\section{Experimental methods}

The measurements took place at two urban locations in Budapest, Hungary. Most measurements were realized at the Budapest platform for Aerosol Research and Training

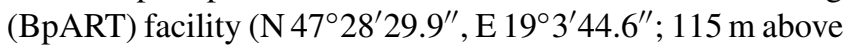
mean sea level (a.s.l.; Salma et al., 2016a). This site represents a well-mixed, average atmospheric environment for the city centre. The other location was situated at the NW border of Budapest in a wooded area of the Konkoly Astronomical Observatory of the Hungarian Academy of Sciences ( $\mathrm{N} 47^{\circ} 30^{\prime} 00.0^{\prime \prime}, \mathrm{E} 18^{\circ} 57^{\prime} 46.8^{\prime \prime} ; 478 \mathrm{~m}$ a.s.l.). This site characterizes the air masses entering the city since the prevailing wind direction in the area is NW. The measurements were accomplished for 6 full-year-long time intervals, i.e. from 3 November 2008 to 2 November 2009, from 19 January 2012 to 18 January 2013, from 13 November 2013 to 12 November 2014, from 13 November 2014 to 12 November 2015, from 13 November 2015 to 12 November 2016 and from 28 January 2017 to 27 January 2018. In the measurement year 2012-2013, the instruments were set up in the near-city background, while in all other years, they were in- 
stalled in the city centre. Local time $(\mathrm{LT}=\mathrm{UTC}+1$ or daylight saving time, UTC +2 ) was chosen as the time base of the data unless otherwise indicated because it had been observed in earlier investigations that the daily activity time pattern of inhabitants substantially influences many atmospheric processes in cities (Salma et al., 2014; Sun et al., 2019).

The main measuring system was a flow-switching type differential mobility particle sizer (DMPS). It consists of a radioactive $\left({ }^{60} \mathrm{Ni}\right)$ bipolar charger, a Nafion semi-permeable membrane dryer, a $28 \mathrm{~cm}$ long Vienna-type differential mobility analyser and a butanol-based condensation particle counter (TSI, model CPC3775). The sample flow was $2.0 \mathrm{~L} \mathrm{~min}^{-1}$ in the high-flow mode and $0.31 \mathrm{~L} \mathrm{~min}^{-1}$ in the low-flow mode, with sheath air flow rates 10 times larger than for the sample flows. The DMPS measures particle number concentrations in an electrical mobility diameter range from 6 to $1000 \mathrm{~nm}$ in the dry state of particles (with a relative humidity of $\mathrm{RH}<30 \%$ ) in 30 channels, which finally yields 27 channels after averaging 3 overlapping channels when joining the data for the two flow modes. The time resolution of the measurements was approximately $10 \mathrm{~min}$ till 18 January 2013 and 8 min from 13 November 2013 (after a planned update of the DMPS system). There was no upper size cut-off inlet applied to the sampling line, and a weather shield and insect net were only attached. The sampling inlets were identical at both locations except for the height of the installation above the ground, which was $12.5 \mathrm{~m}$ in the city centre and approximately $1.7 \mathrm{~m}$ in the near-city background. The measurements were performed according to the international technical standard (Wiedensohler et al., 2012). The availability of the DMPS data over 1-year-long time intervals is summarized in Table 1.

Synoptic meteorological data for air temperature $(T), \mathrm{RH}$, wind speed (WS) and wind direction (WD) were obtained from a measurement station of the Hungarian Meteorological Service (HMS; station no. 12843) by standardized methods with a time resolution of $1 \mathrm{~h}$. Global solar radiation (GRad) data were measured by the HMS at a distance of $10 \mathrm{~km}$ in an easterly direction with a time resolution of $1 \mathrm{~h}$. Meteorological data were available in $>90 \%$ of the possible cases in each year. Concentrations of $\mathrm{SO}_{2}, \mathrm{O}_{3}, \mathrm{NO}_{x}$ and $\mathrm{CO}$ were obtained from measurement stations of the National Air Quality Network in Budapest (in a distance of $4.5 \mathrm{~km}$ from the urban site and of $6.9 \mathrm{~km}$ from the near-city background site) located in the upwind prevailing direction from the measurement sites. They are measured by UV fluorescence (Ysselbach 43C), UV absorption (Ysselbach 49C), chemiluminescence (Thermo 42C) and IR absorption methods (Thermo $48 \mathrm{i}$ ), respectively, with a time resolution of $1 \mathrm{~h}$. The concentration data were available in $>85 \%$ of the yearly time intervals, and $>98 \%$ of them were above the limit of determination (LOD). It is worth mentioning that the LOD of the $\mathrm{SO}_{2}$ analyser was approximately $0.2 \mu \mathrm{g} \mathrm{m}^{-3}$ and that the hourly average $\mathrm{SO}_{2}$ concentration in the Budapest area is ordinarily distributed without larger spatial gradients (Salma et al., 2011). For the present study, this was proved by evaluating the concentration ratios from two different municipal stations which are in the closest distance from the BpART facility in two different directions with an angle of $60^{\circ}$ between them. The mean $\mathrm{SO}_{2}$ concentration ratio and standard deviation (SD) for the two stations were $81 \pm 20 \%$ over the 5-year-long measurement time interval.

\section{Data treatment}

The measured DMPS data were evaluated according to the procedure protocol recommended by Kulmala et al. (2012) with some refinements that are related to urban features (see Sect. 3.1). Particle number concentrations in the diameter ranges from 6 to $1000 \mathrm{~nm}(N)$, from 6 to $25 \mathrm{~nm}\left(N_{6-25}\right)$, from 6 to $100 \mathrm{~nm}$ ( $N_{6-100}$ or UF particles) and from 100 to $1000 \mathrm{~nm}\left(N_{100-1000}\right)$ were calculated from the measured and inverted DMPS concentrations. Particle number size distribution surface plots jointly showing the variation in particle diameter and particle number concentration density in time were also derived. Identification and classification of NPF and growth events was accomplished on these surface plots (Dal Maso et al., 2005; Németh et al., 2018) on a daily basis into the following main classes: NPF event days, non-event days, days with undefined character and days with missing data (for more than $4 \mathrm{~h}$ during the midday). The relative occurrence frequency of events was determined for each month and year as the ratio of the number of event days to the total number of relevant (i.e. all - missing) days. A subset of NPF events with uninterrupted evolution in time, which are called quantifiable (class 1A) events, were further separated because the time evolution of their size distribution functions was utilized to determine the dynamic and timing properties with good accuracy and reliability.

\subsection{Dynamic and timing properties}

Growth rate (GR) of nucleation-mode particles was calculated using a mode fitting method (Kulmala et al., 2012). Particle number median mobility diameter (NMMD) of the nucleation mode was obtained from fitting the individual size distributions using the DoFit algorithm (Hussein et al., 2004). The growth rate was determined as the slope of the linear line fitted to the time series of the NMMD data within a time interval around a diameter $d$, for which the dependency could be satisfactorily approximated by linear fit. Since the nucleation mode was mostly estimated by $N_{6-25}$ in the calculations of the formation rate (see below), and since the median of the related diameter interval (from 6 to $25 \mathrm{~nm}$ ) is close to $d=10 \mathrm{~nm}$, GRs for particles with a diameter of $10 \mathrm{~nm}$ were determined $\left(\mathrm{GR}_{10}\right)$. This type of GR can be interpreted as an average GR as far as the given particle diameter range is concerned, but it actually expresses the beginning of the growth process only. Particle growth can slow substantially 
in time in specific cases, and this can affect the formation rate calculations considerably (see later).

Time evolution of an aerosol population is described by the general dynamic equation which was rearranged, simplified and approximated by several quantities (Kulmala et al., 2001, 2012; Dal Maso et al., 2002; Cai and Jiang, 2017) to express the formation rate $J_{6}$ of particles with the smallest detected diameter of $d_{\min }=6 \mathrm{~nm}$ in a form utilized in the present evaluation as

$$
\begin{aligned}
J_{6} & =\frac{\mathrm{d} N_{6-25}}{\mathrm{~d} t}-\frac{\mathrm{d} N_{A i,<25}}{\mathrm{~d} t}+\operatorname{CoagS}_{10}\left(N_{6-25}-N_{A i,<25}\right) \\
& +\frac{\mathrm{GR}_{10}}{(25-6)}\left(N_{6-25}-N_{A i,<25}\right) .
\end{aligned}
$$

The first term on the right side of Eq. (1) expresses the concentration increment caused by nucleation and particle growth. The particle number concentration in the size range from 6 to $25 \mathrm{~nm}$ (i.e. $N_{6-25}$ ) is usually selected to approximate the nucleation-mode particles $N_{\text {nuc }} \approx N_{6-25}$. This is a reasonable choice because it was proved to be an advantageous and effective way of handling fluctuating data sets since $N_{6-25}$ often exhibits smaller scatter in time and less sensitivity than the fitted area of the nucleation mode. It is implicitly assumed that the intensity of the NPF is constant for a certain time interval, and, therefore, $\mathrm{d} N_{6-25} / \mathrm{d} t$ can be determined as the slope of the linear function of $N_{6-25}$ versus time $t$ within an interval for which the dependence could be satisfactorily approximated by linear fit. A limitation of the relatively wide size range $(6-25 \mathrm{~nm})$ selected can be manifested by disturbances from primary particles, particularly in urban environments. This is taken into account by an additional term of $N_{A i,<25}$, which is discussed below.

The second term on the right side of Eq. (1) expresses the concentration increment caused by high-temperature emission sources, usually of vehicular road traffic (Paasonen et al., 2016; Salma et al., 2017) to $N_{6-25}$, which can provisionally disturb the assumption of $N_{\text {nuc }} \approx N_{6-25}$. A typical example of such a situation is shown in Fig. S1a in the Supplement from 10:09 to 12:23 LT. In these specific cases, the contribution of primary emissions was estimated from the slope of the time series of the fitted peak area of the Aitken mode below $d<25 \mathrm{~nm}\left(N_{A i,<25}\right)$ in the time region under consideration. Reliable separation of the nucleation and Aitken modes from each other was hindered or was not possible for a few individual size distributions due to overlapping modes and the scatter in the measured concentration data, and these individual cases were excluded from or skipped in the time series.

The third term on the right side of Eq. (1) represents the loss of particles due to coagulation scavenging (with preexisting particles). The coagulation scavenging efficiency for particles with a diameter of $10 \mathrm{~nm}\left(\mathrm{CoagS}_{10}\right)$ was selected to approximate the mean coagulation efficiency of nucleationmode particles $\left(\mathrm{Coag} \mathrm{S}_{\mathrm{nuc}}\right)$. This diameter was chosen by considering the median of the related diameter range, which was discussed above for GR. The coagulation efficiency was calculated from classical aerosol mechanics by adopting a mass accommodation coefficient of 1 and utilizing Fuchs' transition-regime correction factor (Kulmala et al., 2001, 2013; Dal Maso et al., 2005) by using computation scripts developed at the University of Helsinki. Self-coagulation within the nucleation mode was neglected due to limited ambient concentrations. Hygroscopic growth of particles was not considered since this depends on chemical composition of particles, which is unknown.

The fourth term on the right side of Eq. (1) expresses the growth out of newly formed particles from the size range through the condensation of vapours. The $\mathrm{GR}_{10}$ was selected to approximate a representative value at the median of the particle diameter range considered (Vuollekoski et al., 2012). It is implicitly assumed that $\mathrm{GR}_{10}$ can be regarded to be constant over the time interval under consideration. Nevertheless, the growth of nucleation-mode particles in time is occasionally limited (Fig. S1b). In these specific cases, the mean relative area of the nucleation mode below $25 \mathrm{~nm}$ was determined by fitting individual size distributions around the time of the maximum nucleation-mode NMMD, and the ratios were averaged. A correction in form of the mean relative area was adopted as a multiplication factor for the growth out term in Eq. (1). On very few days, the growth of newly formed particles was followed by a decrease in nucleation-mode NMMD (Salma et al., 2016a). In these cases, the shrinkage rate (with a formal $\mathrm{GR}_{10}<0$ ) was derived and adopted in Eq. (1). Relative contributions of the concentration increment, coagulation loss and growth out from the diameter interval to $J_{6}$ are decreasing in this order with mean values of $71 \%, 17 \%$ and $12 \%$, respectively (Table S1).

The formation and growth rates for the measurement years of 2008-2009 and 2012-2013 were calculated earlier in a slightly different way and neglecting the urban features discussed above (Salma et al., 2011, 2016b). To obtain consistent data sets, the dynamic properties for these 2 years were re-evaluated by adopting the present improved protocol and implementing the experience gained over the years. The mean new-to-old rate ratios with SDs for the $\mathrm{GR}_{10}$ and $J_{6}$ were $1.06 \pm 0.32$ and $1.23 \pm 0.37$, respectively, in the city centre (2008-2009) and $1.04 \pm 0.21$ and $1.20 \pm 0.35$, respectively, in the near-city background (2012-2013). It was the smaller rates that were primarily and sometimes substantially impacted. The modifications were simultaneously adopted. The subtraction of particle number concentrations emitted by road traffic from $N_{6-25}$ usually leads to a decrease in the coagulation loss term and loss term due to growth out from the diameter range of $6-25 \mathrm{~nm}$. At the same time, the subtraction can also influence the slope of the concentration change in time $\left(\mathrm{d} N_{\text {nuc }} / \mathrm{d} t\right)$ depending on the actual time evolution of perturbing emission source. In addition to that, the time interval in which this slope is considered to be constant was set in a new treatment. It is noted that the relative contributions of the concentration increment, coagulation loss and growth out from the diameter interval to $J_{6}$ have different weights in 
propagating their effects. Furthermore, $J_{6}$ itself also depends on $\mathrm{GR}_{10}$, which makes the relationships even more complex. These connected effects explain why the changes resulted in increments. The recalculation is considered to be a methodological improvement over the years of research.

The assumptions and estimations above usually represent a reasonable approximation to reality. The $N_{6-25}$ is derived from the experimental data in a straightforward way, and the $\mathrm{GR}_{10}$ and the corrections for primary particles and limited particle growth depend on the quality of the size distribution fitting as well, while the $\mathrm{CoagS}_{10}$ is determined using a theoretical model. The resulting accuracies of the dynamic properties, in particular of $J_{6}$, look rather complicated. They also depend on the spatial heterogeneity in the investigated air masses, particularly for the observations performed at the fixed site, size and time resolution of the concentrations measured, diameter range of the size distributions, fluctuations in the experimental data, selection of the particle diameter interval, choice of the time interval of interest (for linear fits), sensitivity of the models to the input uncertainties (Vuollekoski et al., 2012) and also on the extent of the validity of the assumptions applied under highly polluted conditions (Cai and Jiang, 2017). The situation is further complicated with the fact that the dynamic (and also the timing) properties are connected to each other. Finally, it is important to recognize that some NPF and growth curves on the surface plots have a rather broad starting time interval (Fig. S1b and S1c). They occur in a considerable abundance in cities, e.g. in $40 \%$ of all quantifiable events in Budapest (Sect. 4.4). This may yield badly defined or composite dynamic properties, whose uncertainty can have principle limitations which can prevail on the experimental and model uncertainties.

Timing properties of NPF and growth events are increasingly recognized, and they can provide valuable information, even if they are estimated indirectly from the observed diameter interval $>1.5 \mathrm{~nm}$ (Sect. 1). The earliest estimated time of the beginning of a nucleation $\left(t_{1}\right)$ and the latest estimated time of the beginning of a nucleation $\left(t_{2}\right)$ were derived using a comparative method (Németh and Salma, 2014) based on the variation in the content of the first size channel of the DMPS system. Both time parameters include a time shift that accounts for the particle growth from the stable neutral cluster mode at approximately $2 \mathrm{~nm}$ to the smallest detectable diameter limit of the DMPS systems ( $6 \mathrm{~nm}$ in our case) by adopting the GR value in the size window nearest to it in size space. The difference $\Delta t=t_{2}-t_{1}$ is considered to be the duration time interval of the nucleation process. It represents the time interval during which new aerosol particles are generated in the air. The timing properties are expressed in $\mathrm{UTC}+1$, and their uncertainty is regarded to be ca. $30 \mathrm{~min}$ under ordinary NPF and growth situations.

\subsection{Sources and sink}

The relative effects and role of gas-phase $\mathrm{H}_{2} \mathrm{SO}_{4}$ were estimated by its proximity measure (proxy value) containing both its major source and sink terms under steady-state conditions according to Petäjä et al. (2009). It was calculated for GRad $>10 \mathrm{~W} \mathrm{~m}^{-2}$. Formally, it is possible to convert the $\mathrm{H}_{2} \mathrm{SO}_{4}$ proxy values to $\mathrm{H}_{2} \mathrm{SO}_{4}$ concentrations by an empirical scaling factor of $k=1.4 \times 10^{-7} \times \mathrm{GRad}^{-0.70}$, where GRad is expressed in units of $\mathrm{W} \mathrm{m}^{-2}$ (Petäjä et al., 2009). The factor was, however, derived for a remote boreal site, and, therefore, we prefer not to perform the conversion since urban areas are expected to differ from the boreal regions. The conversion was applied only to estimate the order of average $\mathrm{H}_{2} \mathrm{SO}_{4}$ atmospheric concentration levels. The results derived by utilizing the proxy are subject to larger uncertainties than for the other properties because of these limitations, but they may indicate well gross tendencies.

Condensation sink for vapour molecules onto the surface of existing aerosol particles was computed for discrete size distributions as described in earlier papers (Kulmala et al., 2001; Dal Maso et al., 2002, 2005) and summarized by Kulmala et al. (2013). The equilibrium vapour pressure of the condensing species was assumed to be negligible at the surface of the particles, thus similar to sulfuric acid. Dry particle diameters were considered in the calculations.

\section{Results and discussion}

Annual median total particle number concentrations $(N)$ for each measurement year are summarized in Table 1. The data for the city centre indicate a moderate decreasing trend. The mean UF/ $N$ ratios with SD for the same measurement time intervals were $67 \pm 14 \%$ and $79 \pm 6 \%, 75 \pm 10 \%, 75 \pm 11 \%$, $76 \pm 11 \%$ and $80 \pm 10 \%$, respectively. The values correspond to ordinary urban atmospheric environments in Europe (Putaud et al., 2010, Sun et al., 2019). An overview of the number of classified days for each measurement year is also given in Table 1 . The availability of the daily size distribution surface plots with respect to all days ensures that the data are representative on yearly and monthly timescales, except for the months August and September 2015, when there were missing days in larger ratios. The number of quantifiable event days ( 248 cases) is also considerable, which helps us to arrive at a firm conclusion for the NPF and growth events as well.

It was previously shown that the NPF and growth events observed in the city centre of Budapest and its background ordinarily happen above a larger territory or region in the Carpathian Basin (Németh and Salma, 2014), and they are linked to each other as a spatially coherent and joint atmospheric phenomenon (Salma et al., 2016b). From the point of the occurrence frequency distribution, they can, therefore, be evaluated jointly in the first approximation. An over- 
Table 1. Annual median total particle number concentrations (in $10^{3} \mathrm{~cm}^{-3}$ ), number of days with NPF and growth events, quantifiable event days, non-event days, undefined days, missing days and the coverage (in \%) of relevant days in the near-city background and city centre separately for the 1-year-long measurement time intervals.

\begin{tabular}{lr|rrrrr}
\hline Environment & Background & \multicolumn{7}{c}{ Centre } \\
\hline Time & $2012-$ & $2008-$ & $2013-$ & $2014-$ & $2015-$ & $2017-$ \\
interval & 2013 & 2009 & 2014 & 2015 & 2016 & 2018 \\
\hline Concentration & 3.4 & 11.5 & 9.7 & 9.3 & 7.5 & 8.7 \\
Event days & 96 & 83 & 72 & 81 & 35 & 83 \\
Quantifiable days & 43 & 31 & 48 & 56 & 18 & 52 \\
Undefined days & 19 & 34 & 24 & 25 & 8 & 23 \\
Non-event days & 231 & 229 & 267 & 240 & 226 & 257 \\
Coverage & 95 & 95 & 99 & 95 & 73 & 99 \\
Missing days & 20 & 19 & 2 & 19 & 97 & 2 \\
\hline
\end{tabular}

all monthly mean relative occurrence frequency of nucleation days derived for all 6 measurement years is shown in Fig. 1. The annual mean frequency with SD was $22 \pm 5 \%$, which is considerable and is in line with other urban sites (Sect. 1). The monthly mean frequency has a temporal variation, which can be characterized by a noteworthy pattern. The mean monthly dependency exhibits an absolute and a local minimum in January (5.6\%) and August (21\%), respectively, and an absolute and a local maximum in April (40\%) and September $(31 \%)$, respectively. Nevertheless, the SDs of the monthly means indicate prominent variability from year to year. The pattern can be related to multivariate relationships and complex interplay among the influencing factors, which include the air temperature (January is the coldest month, while August is the warmest month in the Carpathian Basin) and enhanced emission of biogenic VOCs in springtime (March-April) and early autumn (September) as well (Salma et al., 2016b). It is noted that the findings derived for the separate city-centre data set are very similar to the results presented above.

The properties and variables studied were derived in full time resolution. They were averaged in several ways for different conditions and for various purposes to obtain typical average descriptive characteristics. In one case (31 August 2016), the NPF and growth event could reliably be identified, while the measured absolute particle number concentrations could not be validated due to experimental difficulties, and, therefore, it was left out from the further calculations. Similarly, there were one and four events with unusually and extraordinarily large dynamic properties in the measurement years 2014-2015 and 2017-2018, respectively. More specifically, five individual $J_{6}$ data when expressed in units of $\mathrm{cm}^{-3} \mathrm{~s}^{-1}$ and one individual $\mathrm{GR}_{10}$ data when given in $\mathrm{nm} \mathrm{h}^{-1}$ were $>20$ (Table 3 ). These extremes were left out from the overview statistics to maintain the representativity (they could be influenced by some unknown extra or very local sources) and to fulfil the basic requirements of correlation analysis better. If an event showed a double beginning then

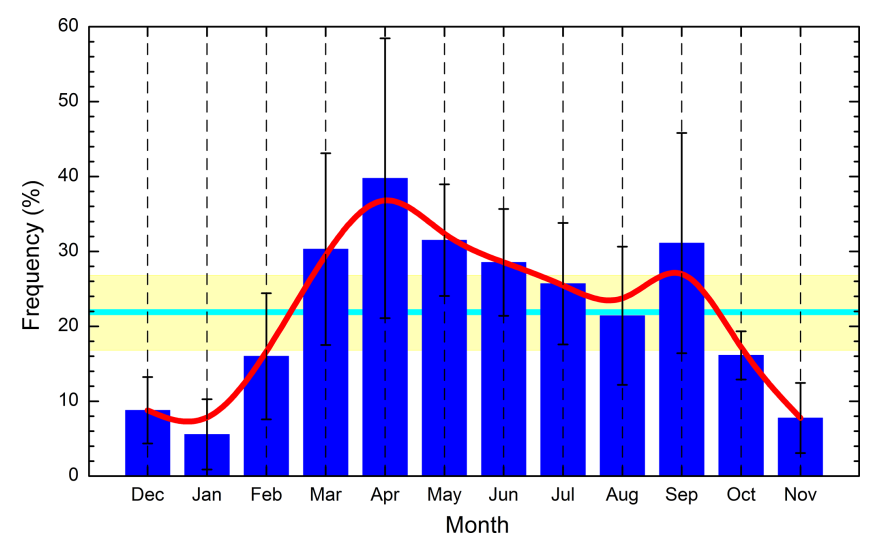

Figure 1. Monthly mean relative occurrence frequency of NPF and growth events for the joint 6-year-long data set. The error bars show \pm 1 standard deviation, the horizontal line in cyan indicates the overall annual mean frequency, the yellow bands represent \pm 1 standard deviation of the annual mean, and the smooth curve in red serves to guide the eye.

the dynamic properties for the first onset were considered in the basic overview since this onset is of regional relevance (Salma et al., 2016b). The extreme NPF and growth events and the characteristics for the second onsets were, however, evaluated separately and are discussed in detail and interpreted in Sect. 4.4.

\subsection{Ranges and averages}

Ranges and averages with SDs of formation rate $J_{6}$, growth rate $\mathrm{GR}_{10}$, starting time of nucleation $\left(t_{1}\right)$ and duration time interval of nucleation $(\Delta t)$ are summarized in Table 2 for separate measurement years and for the joint 5-year-long city centre data set. In the city centre, nucleation generally starts at $09: 15 \mathrm{UTC}+1$, and it is typically maintained for approximately $3 \mathrm{~h}$. The NPF and growth events ordinarily produce 5.6 new aerosol particles with a diameter of $6 \mathrm{~nm}$ in $1 \mathrm{~cm}^{3}$ of air in $1 \mathrm{~s}$ and cause the particles with a diameter of $10 \mathrm{~nm}$ 
Table 2. Ranges, averages and standard deviations of aerosol particle formation rate $J_{6}$, particle diameter growth rate $\mathrm{GR}_{10}$, starting time $\left(t_{1}\right)$ and duration time interval $\left(\Delta t=t_{2}-t_{1}\right)$ of the nucleation process of quantifiable NPF and growth events in the near-city background and city centre separately for the 1-year-long measurement time intervals and for the joint 5-year-long city centre data set.

\begin{tabular}{|c|c|c|c|c|c|c|c|}
\hline \multirow{2}{*}{$\begin{array}{l}\text { Environment } \\
\begin{array}{l}\text { Time } \\
\text { interval }\end{array}\end{array}$} & \multirow{2}{*}{$\begin{array}{r}\text { Background } \\
2012- \\
2013\end{array}$} & \multicolumn{6}{|c|}{ Centre } \\
\hline & & $\begin{array}{r}2008- \\
2009\end{array}$ & $\begin{array}{r}2013- \\
2014\end{array}$ & $\begin{array}{r}2014- \\
2015\end{array}$ & $\begin{array}{r}2015- \\
2016\end{array}$ & $\begin{array}{r}2017- \\
2018\end{array}$ & $\begin{array}{l}\text { All } 5 \\
\text { years }\end{array}$ \\
\hline \multicolumn{8}{|c|}{ Formation rate $J_{6}\left(\mathrm{~cm}^{-3} \mathrm{~s}^{-1}\right)$} \\
\hline Minimum & 0.48 & 1.47 & 1.13 & 0.81 & 1.19 & 1.60 & 0.81 \\
\hline Median & 2.0 & 4.2 & $2-$ & 4.4 & 4.6 & 6.3 & 4.6 \\
\hline Maximum & 5.6 & 15.9 & 17.8 & 18.0 & 15.3 & 17.3 & 18.0 \\
\hline Mean & 2.2 & 4.7 & 5.2 & 5.6 & 5.0 & 6.6 & 5.6 \\
\hline SD & 1.3 & 2.6 & 3.7 & 4.2 & 3.7 & 3.3 & 3.8 \\
\hline \multicolumn{8}{|c|}{ Growth rate $\mathrm{GR}_{10}\left(\mathrm{~nm} \mathrm{~h}^{-1}\right)$} \\
\hline Minimum & 3.0 & 3.7 & 3.1 & 2.8 & 3.2 & 3.3 & 2.8 \\
\hline Medi & 5 & 1. & 6.6 & 6.5 & 8.0 & 7.5 & 7.3 \\
\hline Maximum & 9.8 & 17.4 & 19.0 & 18.0 & 15.5 & 19.8 & 19.8 \\
\hline Mean & 5.2 & 7.8 & 7.2 & 7.3 & 7.7 & 8.0 & 7.6 \\
\hline SD & 1.4 & 2.6 & 2.8 & 3.2 & 3.0 & 2.8 & 2.9 \\
\hline \multicolumn{8}{|c|}{ Starting time, $t_{1}(\mathrm{HH}: \mathrm{mm} \mathrm{UTC}+1)$} \\
\hline Minimum & 05:51 & 07:14 & $06: 44$ & $05: 48$ & 07:31 & 05:57 & $05: 48$ \\
\hline Median & 08:19 & $09: 26$ & 09:22 & $08: 48$ & 09:45 & 09:18 & $09: 15$ \\
\hline Maximum & 11:09 & $11: 38$ & $12: 21$ & $11: 23$ & $12: 45$ & $12: 15$ & $12: 45$ \\
\hline Mean & 08:17 & 09:27 & 09:25 & $08: 49$ & 10:02 & 09:24 & $09: 19$ \\
\hline SD & $01: 11$ & 01:05 & $01: 26$ & $01: 22$ & $01: 23$ & $01: 36$ & $01: 26$ \\
\hline \multicolumn{8}{|c|}{ Duration time, $\Delta t(\mathrm{HH}: \mathrm{mm})$} \\
\hline Minimum & 01:23 & $00: 52$ & $00: 42$ & $00: 31$ & 01:03 & $01: 26$ & $00: 31$ \\
\hline Median & $03: 16$ & $02: 36$ & 02:04 & 03:53 & $02: 31$ & 03:49 & $02: 57$ \\
\hline Maximum & $06: 44$ & 06:04 & $05: 34$ & $07: 46$ & 06:05 & $07: 55$ & $07: 55$ \\
\hline Mean & 03:30 & 02:44 & $02: 14$ & 03:52 & $02: 58$ & 03:57 & $03: 18$ \\
\hline SD & 01:40 & 01:11 & 01:01 & 01:40 & $01: 47$ & 01:39 & $01: 40$ \\
\hline
\end{tabular}

to grow at a typical rate of $7.6 \mathrm{~nm} \mathrm{~h}^{-1}$. The statistics for $J_{6}$ and $\mathrm{GR}_{10}$ are based on 199 and 203 events, respectively. The corresponding data for the separate years show considerable variability without obvious trends or tendencies. The differences between the years can likely be related to changes in actual atmospheric chemical and physical situations and conditions and to the resulting modifications in the sensitive balance and delicate coupling among them from year to year. Spread of the individual data for $\mathrm{GR}_{10}$ is smaller than for $J_{6}$; the relative SDs for the joint 5-year-long city centre data set were $38 \%$ and $68 \%$, respectively.

The dynamic properties and $t_{1}$ data tend to be smaller in the near-city background than in the city centre. In general, nucleation starts $1 \mathrm{~h}$ earlier in the background, and the events typically show significantly smaller $J_{6}$ (with a median of $2.0 \mathrm{~cm}^{-3} \mathrm{~s}^{-1}$ ) and $\mathrm{GR}_{10}$ (with a median of $5.0 \mathrm{~nm} \mathrm{~h}^{-1}$ ). Duration of the nucleation is very similar to that in the city centre. All starting times of nucleation were larger than (in a few cases, very close to) the time of the sunrise. This implies that no nocturnal NPF and growth event has been identified in Budapest so far. The particle growth process (the so-called "banana" curve) could be traced usually for a longer time interval (up to $1.5 \mathrm{~d}$ ) in the background than in the centre.

These results are in line with ideas on atmospheric nucleation and the consecutive particle growth process (e.g. Kulmala et al., 2014; Zhang et al., 2015; Kerminen et al., 2018). It was observed in a recent overview study (Nieminen et al., 2018) that the formation rate of $10-25 \mathrm{~nm}$ particles increased with the extent of anthropogenic influence, and in general, it was 1-2 orders of magnitude larger in cities than at sites in remote and clean environments.

Ranges and averages with SDs of some related atmospheric properties, namely of mean condensation sink (CS) averaged for the time interval from $t_{1}$ to $t_{2}$, daily maximum gas-phase $\mathrm{H}_{2} \mathrm{SO}_{4}$ proxy, daily mean $T$ and $\mathrm{RH}$ (Table S2) and of daily median concentrations of $\mathrm{SO}_{2}$ (as the major precursor of gas-phase $\mathrm{H}_{2} \mathrm{SO}_{4}$ ), $\mathrm{O}_{3}$ (as an indicator of photochemical activity), $\mathrm{NO}_{x}$ and $\mathrm{CO}$ gases (as indica- 
tors of anthropogenic combustion activities and road vehicle emissions) (Table S3) were also derived for quantifiable NPF and growth event days and are further evaluated. The annual mean CS values exhibited decreasing tendency in the city centre over the years. The individual values remained below approximately $20 \times 10^{-3} \mathrm{~s}^{-1}$, which agrees well with the results of our earlier study (Salma et al., 2016b) according to which the CS suppresses NPF above this level in the Carpathian Basin. Maximum $\mathrm{H}_{2} \mathrm{SO}_{4}$ proxy values reached substantially higher levels (by a factor of approximately 2) in the near-city background than in the city centre, mainly due to the differences in the $\mathrm{CS}$ and $\left[\mathrm{SO}_{2}\right]$. The differences between the two sites are particularly evident when considering their smallest values. The largest variability in the annual average values was observed for the proxy. Median concentration of $\mathrm{H}_{2} \mathrm{SO}_{4}$ molecules was roughly estimated to be approximately $5 \times 10^{5} \mathrm{~cm}^{-3}$ by adopting the scaling factor, although it is largely uncertain due to the limitations of the factor (Sect. 3.2). The air $T$ displayed quite similar and comparable values over the years at both sites. The discussion of its overall effect on the dynamic properties is accomplished in Sect. 4.2, where the monthly distributions are presented. Some events happened at daily mean temperatures below zero. The daily mean RH and its SD for the city centre and near-city background were $54 \pm 11 \%$ and $64 \pm 12 \%$, respectively. There were events that occurred at RHs as high as $90 \%$. Relationships of the dynamic properties with $T$ and $\mathrm{RH}$ are also obscured by the strong seasonal cycle of these meteorological data and by the fact that air masses arriving at the receptor site in different trajectories are often characterized by distinct levels of meteorological data.

As far as the pollutant gases are concerned (Table S3), $\mathrm{SO}_{2}$ showed somewhat smaller daily median values, and $\mathrm{O}_{3}$ exhibited substantially smaller levels on event days in the city centre than in the near-city background, while concentrations of $\mathrm{NO}_{x}$ and $\mathrm{CO}$ were obviously larger in the city than in its close background. The differences can primarily be explained by intensity and spatial distribution of their major sources and atmospheric chemical reactions, and the joined concentration data resemble typical situations without photochemical smog episodes in cities. There was no obvious decrease in $\mathrm{SO}_{2}$ concentration during these years in contrast with an earlier decreasing trend from the mid-1980s till about 2000 .

\subsection{Monthly distributions}

Distributions of the monthly mean $J_{6}, \mathrm{GR}_{10}$, daily maximum gas-phase $\mathrm{H}_{2} \mathrm{SO}_{4}$ proxy, mean CS, daily mean air $T$ and $\mathrm{RH}$ and daily median $\mathrm{SO}_{2}, \mathrm{O}_{3}, \mathrm{NO}_{x}$ and $\mathrm{CO}$ concentrations for quantifiable NPF and growth events for the joint city centre data sets are shown in Fig. 2. The distributions - eminently for $J_{6}, \mathrm{GR}_{10}, \mathrm{H}_{2} \mathrm{SO}_{4}$ proxy and $\mathrm{SO}_{2}$ - do not follow the monthly pattern of the event occurrence frequency at all (cf. Fig. 1). Instead, the $J_{6}, \mathrm{GR}_{10}$ and $\mathrm{H}_{2} \mathrm{SO}_{4}$ proxy tend to exhibit larger values in summer months, and the temporal changes over the other months are smooth and do not show distinctive features. The elevations are substantial; the estimated maximum level was larger than the baseline by a factor of 2.1 for the $J_{6}$ and by a factor of approximately 1.4 for the $\mathrm{GR}_{10}$ and $\mathrm{H}_{2} \mathrm{SO}_{4}$ proxy. Intensity of solar radiation, its seasonal cycling, concentration of atmospheric precursors in different months, biogenic processes, anthropogenic activities and the fact that rate coefficients of many thermal chemi$\mathrm{cal} / \mathrm{physicochemical}$ processes in nature (including GR; Paasonen et al., 2018) increase with $T$ could play an important role in explaining the distributions.

The differences in the GRad (and some other properties) are, however, biased by the seasonal cycle of solar electromagnetic radiation via the seasonal variation of NPF occurrence frequency. Nevertheless, the misalignment among the monthly distributions of NPF and growth event occurrence frequency and all the other properties indicates that the occurrence or its basic causes are not linked with the dynamic properties in a straightforward or linear manner in the Carpathian Basin, including Budapest.

Some of our results are in line with other observations according to which GR exhibited almost exclusively a summer maximum, while some other findings are different in the sense that the seasonal variability in particle formation rate was quite modest and could not be established earlier (Nieminen et al., 2018). There is one more aspect which may be worth realizing in this respect. A large fraction of compounds contributing to NPF and growth in cities can originate from anthropogenic precursors (Vakkari et al., 2015). Their emissions may peak any time of the year depending on human habits and requirements (Nieminen et al., 2018). Nevertheless, the fact that our monthly distributions of the dynamic properties in urban environments follow the universal summer maximum behaviour may indicate the overall prevailing role of atmospheric photochemistry coupled with biogenic emissions of aerosol precursor vapours.

The monthly mean $J_{6}, \mathrm{GR}_{10}$ and $\mathrm{H}_{2} \mathrm{SO}_{4}$ proxy data still have considerable uncertainty, which makes their interpretation not yet completely conclusive. The uncertainties are influenced by inherent fluctuations in the primary data sets, enhancing effects caused by combining some individual primary data into compound variables (such as $\mathrm{H}_{2} \mathrm{SO}_{4}$ proxy), number of data items available for different properties and months, variations in other or unknown relevant environmental conditions and by the variability in relative nucleation occurrence frequency from year to year. The resulting uncertainties are expected to decrease with the length of the available data sets, which emphasizes the need to continue the measurements.

The monthly distributions of CS and $\mathrm{SO}_{2}$ and $\mathrm{NO}_{x}$ concentrations could be represented by constant values of the overall means and SDs of $(9.4 \pm 4.3) \times 10^{-3} \mathrm{~s}^{-1}, 4.7 \pm$ $2.1 \mathrm{\mu g} \mathrm{m}^{-3}$ and $81 \pm 38 \mu \mathrm{g} \mathrm{m}^{-3}$, respectively, with an acceptable accuracy. This suggests that these variables in Budapest 


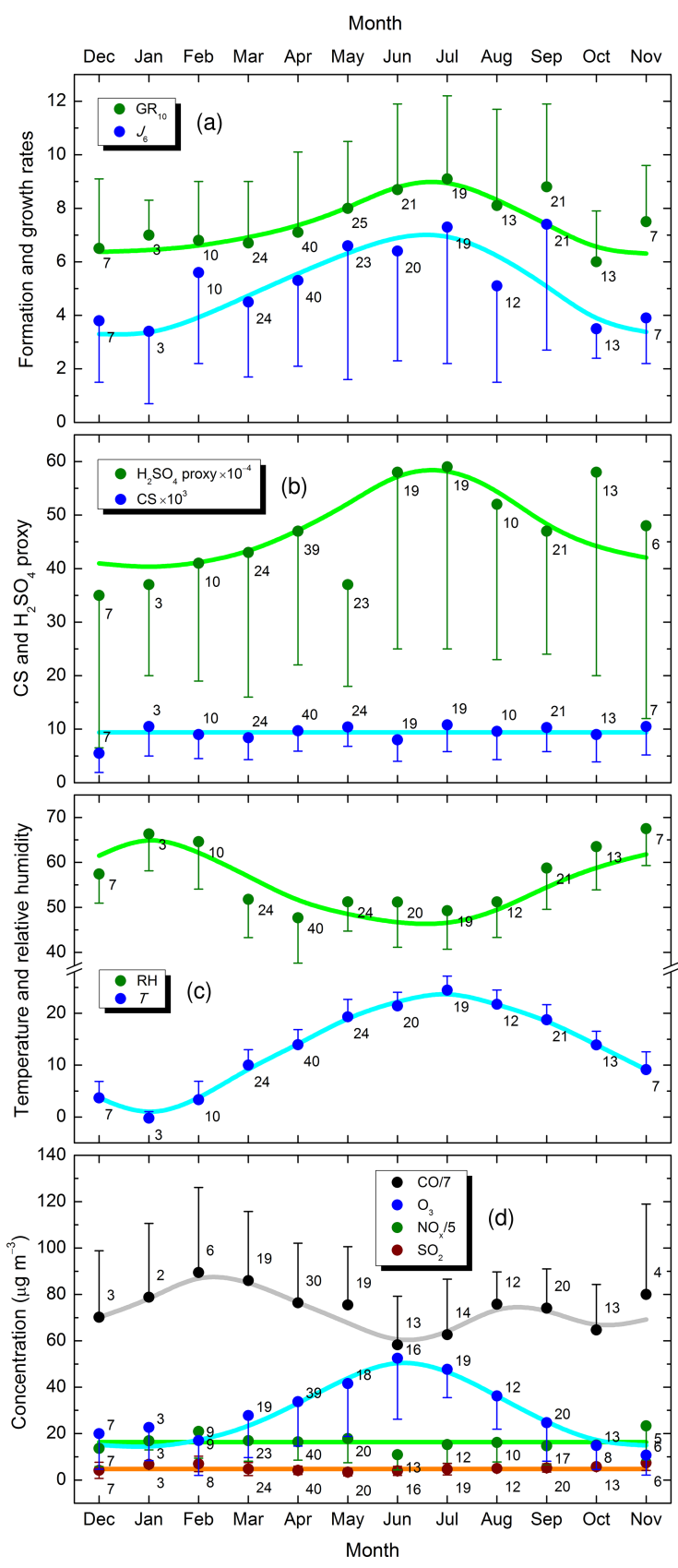

Figure 2. Distribution of monthly mean aerosol particle formation rate $J_{6}$ in units of $\mathrm{cm}^{-3} \mathrm{~s}^{-1}$ and particle diameter growth rate $\mathrm{GR}_{10}$ in units of $\mathrm{nm} \mathrm{h}^{-1}$ (a), mean condensation sink for vapours (CS) in units of $\mathrm{s}^{-1}$ averaged over the nucleation time interval $\left(t_{1}, t_{2}\right)$ and daily maximum gas-phase $\mathrm{H}_{2} \mathrm{SO}_{4}$ proxy in units of $\mu \mathrm{g} \mathrm{m}^{-5} \mathrm{~W} \mathrm{~s}$ (b), daily mean air temperature $(T)$ in units of ${ }^{\circ} \mathrm{C}$ and daily mean relative humidity ( $\mathrm{RH})$ in $\%$ (c) and daily median concentrations of $\mathrm{SO}_{2}, \mathrm{O}_{3}, \mathrm{NO}_{x}$ and $\mathrm{CO}$ for quantifiable NPF and growth events in the city centre for the joint 5-year-long time interval. The error bars are shown for one side and indicate 1 standard deviation. The number of individual data averaged in each month is displayed next to the symbols. The horizontal lines indicate the overall mean. The non-linear curves assist to guide the eye. do not critically or substantially affect the dynamic properties (or the event occurrence). Monthly distributions of air $T$ and $\mathrm{O}_{3}$ concentration showed a maximum over summer months, while $\mathrm{RH}$ reflected the $T$ tendency. In addition, monthly averages of $T$ on event days and on non-event days were similar. Both higher biogenic emissions and typically stronger photochemistry are expected during the summer, which enhance the production rate of nucleating and condensing vapours, while there is practically nothing extra in the first approximation (except for extreme $T \mathrm{~s}$ ) that would suppress the dynamical properties (Kerminen et al., 2018). As a result of these complex effects, the dynamic rates showed a summer maximum. This is consistent with the results from other urban and non-urban studies (Nieminen et al., 2018). The distribution of CO was more variable and without obvious tendentious temporal structure or feature than for the other gases, and, therefore, its interpretation has been encumbered so far. However, this does not seem to substantially affect the dynamic properties.

Distributions of monthly average ratios of major variables on NPF event days to that on non-event days for the joint city centre data set are summarized in Fig. 3. It is noted that the differences in the number of non-event days and event days are the largest in winter and smallest in spring (Fig. 1). The annual mean ratios for $N_{6-100}, \mathrm{GRad}, \mathrm{SO}_{2}$ and $\mathrm{O}_{3}$ were above unity, and for $N_{100-1000}$ and $\mathrm{RH}$, they were below unity, while the value of $\mathrm{CS}, \mathrm{NO}_{x}$ and $\mathrm{CO}$ were close to each other on both types of days. Ultrafine particles are generated by NPF and growth processes in a considerable amount; their concentration was larger by $23 \%$ on event days than on non-event days. This agrees with our earlier assessment of the NPF contribution as a single source of particles based on the nucleation strength factor $\mathrm{NSF}_{\mathrm{GEN}}$ of $13 \%$ as a lower estimate (Salma et al., 2017). The other variables of the first group above represent conditions which favour atmospheric nucleation and particle growth, i.e., strong solar radiation, precursor gas and general photochemical activity, respectively. Particles in the size range of 100-1000 nm (the pre-existing particles with a relatively long residence time) express condensation and scavenging sink, which represents a competing process to nucleation. There is also evidence that RH acts against continental NPF processes (Hamed et al., 2011).

It is also seen in Fig. 3 that NPF and growth events in winter took place preferably when $N_{100-1000}, \mathrm{CS}, \mathrm{RH}, \mathrm{NO}_{x}$, and $\mathrm{CO}$ concentrations were especially low and $\mathrm{O}_{3}$ concentration was unusually large. It can be explained by considering that the basic preconditions of NPF events are realized by the ratio of source and sink terms for condensing vapours. The source strength in winter is often decreased substantially in the Budapest area (Salma et al., 2017) due to lower solar radiation and less (biogenic) chemical precursors in the air. Nevertheless, NPF can still occur if the sink becomes even smaller. This also explains the relatively low event day-tonon-event day ratios for $N_{6-100}$ observed in winter months. 


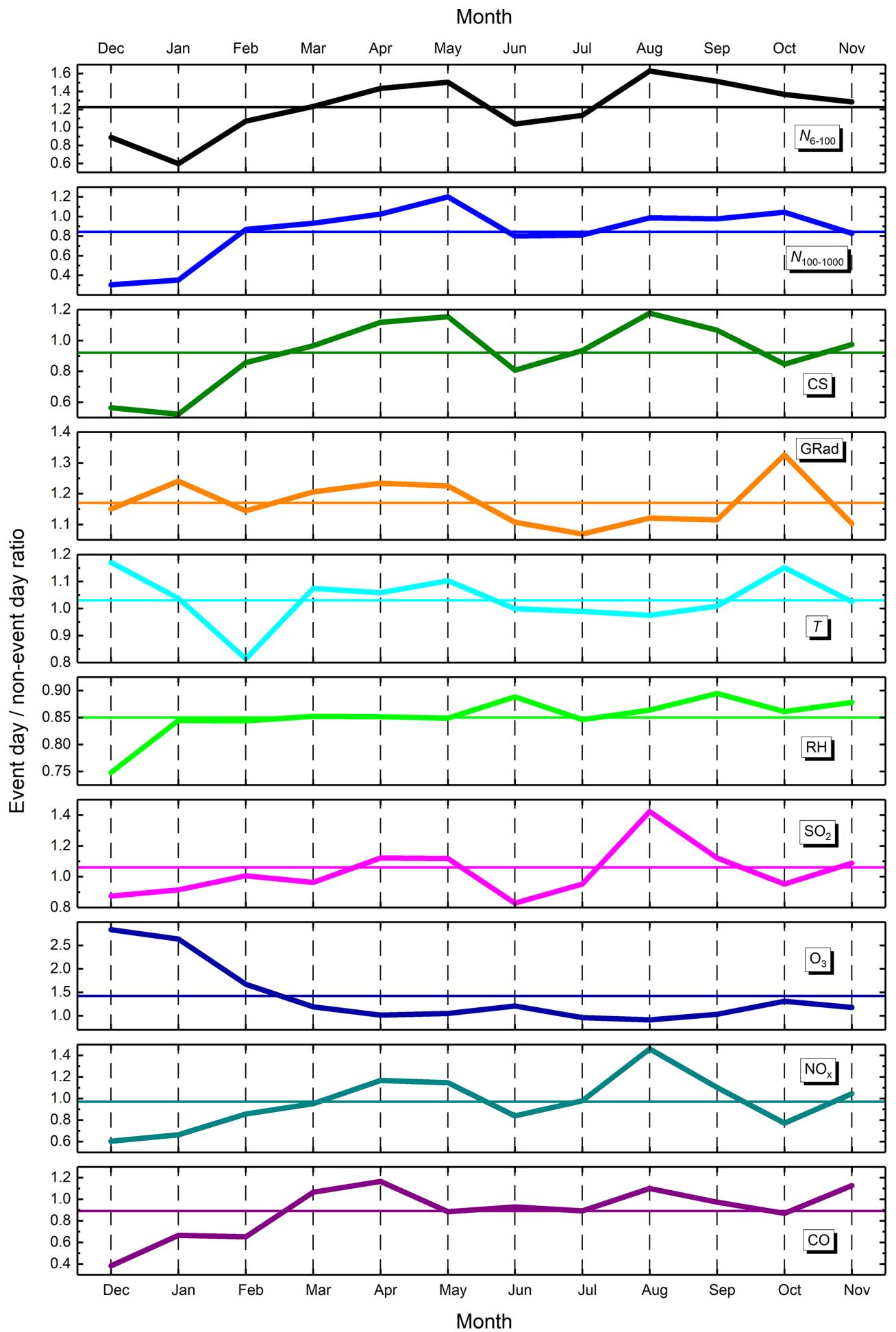

Figure 3. Distributions of ratios for monthly median concentrations of $N_{6-100}, N_{100-1000}, \mathrm{SO}_{2}, \mathrm{O}_{3}, \mathrm{NO}_{x}$ and $\mathrm{CO}$, and for monthly mean condensation sink for vapours (CS), global solar radiation (GRad), air temperature $(T)$ and relative humidity (RH) on NPF event days to that on non-event days in the city centre for the joint 5-year-long time interval. The horizontal lines represent annual mean ratios. 
Full exploitation of the database by multi-statistical and other methods has been in progress and is to be published in a separate article.

\subsection{Relationships}

Pearson's coefficients of correlation $(R)$ between $J_{6}$ and $\mathrm{GR}_{10}$ revealed a significant linear relationship for all annual data sets (the mean $R$ and SD were $0.768 \pm 0.099$, number of data pairs $n=243$ ). This confirms that formation of new aerosol particle and their growth to larger sizes are tightly and positively linked together. It should be noted that $J_{6}$ and $\mathrm{GR}_{10}$ are not completely independent variables (see Eq. 1 and Table S1). The linear relationship between the dynamic properties was observed under different atmospheric conditions in many environments (Nieminen et al., 2018).

The dynamic properties can also be coupled to the concentrations of aerosol precursor compounds and properties of a pre-existing particle population, thus to the atmospheric environment (Kerminen et al., 2018). It is, therefore, sensible to investigate the city centre and near-city background data separately. Scatter plots between $J_{6}$ and $\mathrm{GR}_{10}$ for the 1 -yearlong measurement time intervals are shown in Fig. 4. For the city centre, the regression lines follow the line with a slope of 1 in all 5 years. The mean slope $(b)$ with SD for the joint 5 year-long city centre data set was $b=0.94 \pm 0.07$ expressed formally in units of $\mathrm{cm}^{-3} \mathrm{~s}^{-1} \mathrm{~nm}^{-1} \mathrm{~h}$. At the same time, the regression line for the near-city background deviated significantly with a $b=0.67 \pm 0.10 \mathrm{~cm}^{-3} \mathrm{~s}^{-1} \mathrm{~nm}^{-1} \mathrm{~h}$ from the $J_{6}$ versus $\mathrm{GR}_{10}$ dependency for the city centre. This can imply that NPF and growth processes advance in a different manner in these two environments. This is likely related to the differences between the city and its close environment as far as the atmospheric composition (for instance, the VOC and $\mathrm{NO}_{x}$ concentrations), chemistry and physics and other delicate conditions are concerned (Paasonen et al., 2018). The narrower range and smaller number of individual dynamic properties available for the near-city background relative to those in the city centre represent some inherent limitation or weakness in the explanation, and, therefore, it can only strictly be regarded as a working hypothesis.

The intercepts $(a)$ of the regression lines were identical for all data sets within their uncertainty interval. The mean intercept and SD were estimated to be $-1.7 \pm 0.8 \mathrm{~cm}^{-3} \mathrm{~s}^{-1}$. This finding is interpreted as the existence of a minimum GR or more exactly of a minimally required GR that leads to $J_{6}>0$. Particles that exhibit at least this level of GR can escape coagulation mainly with larger particles and reach the detectable diameter ( $6 \mathrm{~nm}$ in our case) by condensational growth. The minimal GR was derived as $\mathrm{GR}_{\min }=-a / b$, and its mean and $\mathrm{SD}$ are $1.8 \pm 1.0 \mathrm{~nm} \mathrm{~h}^{-1}$ for the conditions ordinarily present in the Budapest air. Nucleation processes which are initiated under circumstances that cause the newly formed particle with a diameter of $10 \mathrm{~nm}$ to grow at a rate of $<\mathrm{GR}_{\min }$ are normally not observed. Anyway, these are expected to be events with relatively small $J_{6}$ (weak phenomena) due to the relationship between $\mathrm{GR}_{10}$ and $J_{6}$. The events with GR larger but close to this limit could still be masked by fluctuating experimental data. Their identification and evaluation can be made feasible by decreasing the lower measurement diameter limit of DMPS systems down to $3 \mathrm{~nm}$ or by using different instruments such as a particle size magnifier or neutral cluster and air ion spectrometer.

Correlations between individual $\mathrm{H}_{2} \mathrm{SO}_{4}$ proxy values on one side and $J_{6}$ or $\mathrm{GR}_{10}$ on the other side were not significant. This is consistent with the corresponding conclusion of Sect. 4.2 and with the earlier results according to which the mean contribution of $\mathrm{H}_{2} \mathrm{SO}_{4}$ condensation to the particle $\mathrm{GR}_{10}$ was only $12.3 \%$ in Budapest (Salma et al., 2016b). The lack of correlation and the average concentrations of $\mathrm{SO}_{2}$ derived separately for event and non-event days suggest that this precursor gas is ordinarily available in excess, and, therefore, it is usually not the lack of $\mathrm{SO}_{2}$ gas itself which limits the NPF and growth events in Budapest. Instead, the reaction rate of oxidation of $\mathrm{SO}_{2}$ to $\mathrm{H}_{2} \mathrm{SO}_{4}$ in the gas phase - likely governed by photochemical conditions - and chemical species other than $\mathrm{H}_{2} \mathrm{SO}_{4}$ can have a larger influence on the particle growth. The role of $\mathrm{H}_{2} \mathrm{SO}_{4}$ in the nucleation process and early particle growth could still be determinant or relevant.

Coefficients of correlation between CS on one side and $J_{6}$ or $\mathrm{GR}_{10}$ on the other side for the joint city centre data sets were modest ( $R=0.41$ and 0.32 , respectively, with $n=194$ and 197, respectively). This is simply related to the fact that larger GR values are typical of polluted urban air (Kulmala et al., 2017) since particles capable of escaping coagulation scavenging need to grow faster in comparison to cleaner environments, and the enhanced requirements for the growth are linked to increased formation rates as well. It should be noted here that the GR of newly formed particles to larger sizes is primarily coupled to (1) CS, which is further linked to the entire aerosol particle population (including the newly formed particles, thus the NPF itself), (2) to the total concentration and some physicochemical properties of non-volatile gaseous compounds and (3) to their production rate in the gas phase from aerosol precursor compounds (e.g. Kerminen et al., 2018). These couplings could result in rather complex behaviour, and their understanding is essential when analysing atmospheric observations.

As far as the pollutant gases are concerned, no correlation could be identified between $J_{6}$ or $\mathrm{GR}_{10}$ on one side and the gas concentrations on the other side. The coefficients of correlation between $\mathrm{CS}$ and $\mathrm{NO}_{x}$ or $\mathrm{CO}$ were modest $(R=0.37$ and 0.42 , respectively, with $n=164$ and 152, respectively), while correlation of $\mathrm{NO}_{x}$ and $\mathrm{CO}$ on one side with WS was also modest but negative $(R=-0.32$ and -0.42 , respectively, with $n=167$ and 155 , respectively). The former relationships can be explained by the fact that vehicular road traffic in cities is a considerable and common source of $\mathrm{NO}_{x}$, $\mathrm{CO}$ and primary particles (Paasonen et al., 2016), and the 

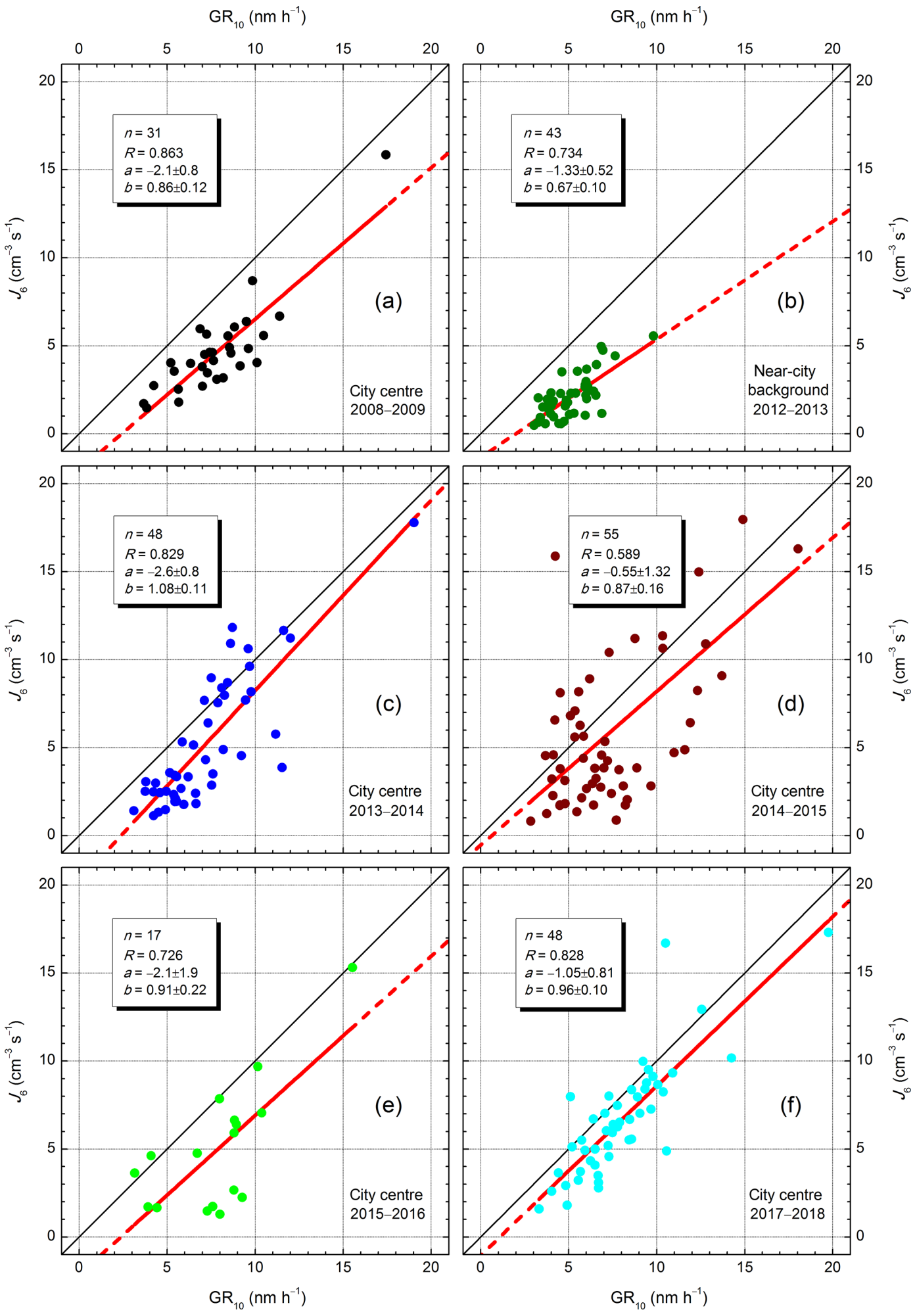

Figure 4. Scatter plots for aerosol particle formation rate $J_{6}$ and particle diameter growth rate $\mathrm{GR}_{10}$ in city centre (a, c-f) and near-city background (b) separately for the 1-year-long measurement time intervals. Number of data points $(n)$, their coefficient of correlation $(R)$ and the intercept $(a)$ and slope $(b)$ of the regression line with standard deviations are also indicated. The lines in black represent the line with a slope of 1 , and the solid lines in red show the regression lines, while the dashed parts in red are extrapolated from the regression line. 
Table 3. Date, new particle formation rate $J_{6}$ (in units of $\mathrm{cm}^{-3} \mathrm{~s}^{-1}$ ), particle diameter growth rate $\mathrm{GR}_{10}\left(\mathrm{~nm} \mathrm{~h}^{-1}\right)$, starting time $t_{1}$ of nucleation $(\mathrm{HH}: \mathrm{mm} \mathrm{UTC}+1)$, duration time interval $\Delta t=t_{2}-t_{1}$ of nucleation $(\mathrm{HH}: \mathrm{mm})$, mean condensation sink CS during the nucleation process $\left(10^{-3} \mathrm{~s}^{-1}\right)$, daily maximum gas-phase $\mathrm{H}_{2} \mathrm{SO}_{4}$ proxy $\left(10^{4} \mu \mathrm{g} \mathrm{m}{ }^{-5} \mathrm{~W} \mathrm{~s}\right)$, daily mean air temperature $T\left({ }^{\circ} \mathrm{C}\right)$, daily mean relative humidity $\mathrm{RH}(\%)$, daily median concentrations of $\mathrm{SO}_{2}, \mathrm{O}_{3}, \mathrm{NO}_{x}\left(\mu \mathrm{g} \mathrm{m}^{-3}\right)$ and $\mathrm{CO}\left(\mathrm{mg} \mathrm{m}^{-3}\right)$ gases and the type of the onset for extreme quantifiable NPF and growth events. The numbers in italics indicate the values which are above the $98 \%$ percentile of the corresponding data sets. NA: not available.

\begin{tabular}{llllllllll}
\hline $\begin{array}{l}\text { Date/ } \\
\text { property }\end{array}$ & $\begin{array}{l}\text { 15 September } \\
2009\end{array}$ & $\begin{array}{l}\text { 20 April } \\
2014\end{array}$ & $\begin{array}{l}\text { 19 May } \\
2015\end{array}$ & $\begin{array}{l}\text { 4 July } \\
2015\end{array}$ & $\begin{array}{l}\text { 28 May } \\
2017\end{array}$ & $\begin{array}{l}\text { 25 June } \\
2017\end{array}$ & $\begin{array}{l}\text { 2 August } \\
2017\end{array}$ & $\begin{array}{l}\text { 31 August } \\
2017\end{array}$ & $\begin{array}{l}\text { 9 September } \\
2017\end{array}$ \\
\hline$J_{6}$ & 15.9 & 17.8 & 24 & 16.3 & 27 & 33 & 30 & 47 & 17.3 \\
$\mathrm{GR}_{10}$ & 17.4 & 19.0 & 12.2 & 18.0 & 9.2 & 17.0 & 11.8 & 21 & 19.8 \\
$t_{1}$ & $10: 20$ & $08: 52$ & $08: 52$ & $09: 38$ & $06: 34$ & $10: 18$ & $07: 39$ & $10: 06$ & $11: 38$ \\
$\Delta t$ & $01: 23$ & $01: 42$ & $03: 57$ & $02: 06$ & $07: 15$ & $02: 46$ & $06: 58$ & $06: 19$ & $02: 06$ \\
$\mathrm{Proxy}$ & 38 & 42 & 25 & 16 & 229 & 41 & 69 & 92 & 45 \\
$\mathrm{CS}$ & 13.4 & 8.9 & 13.7 & 11.9 & 6.9 & 10.5 & 23 & 18.2 & 15.5 \\
$T$ & 20 & 13.0 & 22 & 26 & 20 & 24 & 29 & 23 & 19.1 \\
$\mathrm{RH}$ & 60 & 62 & 48 & 40 & 40 & 68 & 49 & 47 & 58 \\
$\mathrm{SO} 2$ & 6.1 & 2.5 & 4.4 & 2.3 & 3.4 & 3.1 & 5.6 & 8.1 & 6.6 \\
$\mathrm{O}_{3}$ & 16.3 & 43 & NA & 33 & 61 & 56 & 34 & 24 & 12.9 \\
$\mathrm{NO}_{x}$ & 69 & 34 & 174 & 70 & 44 & 66 & NA & 109 & 112 \\
$\mathrm{CO}$ & 0.42 & NA & 0.71 & 0.33 & 0.31 & 0.50 & 0.97 & 0.62 & 0.71 \\
Onset & ordinary & double & broad & ordinary & broad & broad & broad & broad & ordinary \\
\hline
\end{tabular}

emitted particles largely contribute to CS levels. The latter relationships are linked to the effect of large-scale air mass transport (often connected to high WSs) on urban air pollution or air quality.

\subsection{Extreme and multiple events}

The data sets of $J_{6}, \mathrm{GR}_{10}$ and $\Delta t$ containing all 247 individual values each could be characterized by a log-normal distribution function. This is demonstrated by a log-probability graph for $J_{6}$ in Fig. S2 as an example. The coefficient of determination, median and geometric standard deviation for $J_{6}, \mathrm{GR}_{10}$ and $\Delta t$ data sets were $0.990,4.0 \mathrm{~cm}^{-3}$ and 2.3 ; $0.993,6.8 \mathrm{~nm} \mathrm{~h}^{-1}$ and 1.46; and 0.998, 02:57 (0.123 d) and 1.74 , respectively. It is noted that the findings derived for the separate city centre data set are very similar to the results presented above.

One of the major properties of this distribution type is that it contains relatively large individual data with considerably high abundances. There were five individual $J_{6}$ and five individual $\mathrm{GR}_{10}$ data above the $98 \%$ percentile of the data sets, which belonged to nine separate NPF and growth events (days). Their specifications, properties and parameters are summarized in Table 3. All these events occurred in the city centre from April to September. The medians of $J_{6}, \mathrm{GR}_{10}$, CS and air $T$ for the subsets of these 9 extreme event days were larger by factors of 5.2, 2.4, 1.5 and 1.4, respectively, than for the city centre data. At the same time, the medians of the other atmospheric properties and concentrations in these two respective data sets agreed to within approximately $10 \%$. There was a single event associated with an extreme $\mathrm{H}_{2} \mathrm{SO}_{4}$ proxy (of $23 \times 10^{5} \mu \mathrm{g} \mathrm{m}{ }^{-5} \mathrm{~W} \mathrm{~s}$ ) and relatively low
$\mathrm{NO}_{x}$ concentration $\left(44 \mu \mathrm{g} \mathrm{m}^{-3}\right)$, which indicate exceptionally favourable conditions for NPF and growth. In addition to this case, there were only a few days that were characterized by an unusually large $\mathrm{CS}\left(23 \times 10^{-3} \mathrm{~s}^{-1}\right)$ - which could in turn be linked to higher dynamic rates (Sect. 4.3) - or by somewhat larger $\mathrm{SO}_{2}\left(8.1 \mu \mathrm{g} \mathrm{m}^{-3}\right)$ or lower $\mathrm{NO}_{x}$ concentration $\left(34 \mu \mathrm{g} \mathrm{m}^{-3}\right)$. For all the other events, however, no simple or compound property of the investigated variables could explain the extreme rates. Instead, they may be related to some other chemical species and/or atmospheric processes, which were not including in the present study.

Each quantifiable NPF and growth event was labelled as ordinary or broad by visual inspection of its beginning part. If the width of the beginning was smaller than approximately $2 \mathrm{~h}$, or there was a determinant single growth curve (rib) on the size distribution surface plot, then the onset was labelled as ordinary, otherwise as broad (Fig. S1b and S1c for broad onsets). Broad onsets can be generated by (1) a long-lasting nucleation process, (2) nucleation that has been disrupted and has started over due to changing atmospheric and meteorological conditions or (3) multiple nucleation processes close to each other in time (Salma et al., 2016b). The broad onsets were specified as doublets if the nucleation mode could be separated into two submodes by size distribution fitting. Approximately $40 \%$ of all quantifiable events had a broad onset. This indicates that events with broad or multiple onsets are abundant in the urban environment, which could be an important difference from remote or clean atmospheres.

For ca. $10 \%$ of all quantifiable event days, it was feasible to calculate two sets of dynamic properties for onsets 1 and 2 with reasonable accuracy. In the near-city background, the 
medians of $J_{6}$ and $\mathrm{GR}_{10}$ for onset 1 were similar to the corresponding medians for the whole near-city background data set, while for onset 2 , they were substantially larger, namely $4.1 \mathrm{~cm}^{-3} \mathrm{~s}^{-1}$ and $10.0 \mathrm{~nm} \mathrm{~h}^{-1}$, respectively (cf. Table 2). Actually, the latter values were closer to the medians of the city centre than for the near-city background. Approximately $75 \%$ of the doublets resulted in individual onset $2 /$ onset 1 ratios larger than unity. Their overall median ratios for $J_{6}$ and $\mathrm{GR}_{10}$ were similar and approximately 1.2 , while for the near-city background, they were about 2 . The results are in line with our earlier conclusion according to which the second onsets (if it is a new formation process and not just an event that has started over) are more intensive than the first onsets (Salma et al., 2016b). These particles also grow faster. This can be explained by the fact that the first event is of a regional scale since its dynamic properties resemble those of the regional background (Yli-Juuti et al., 2009), while the later event can be characterized by values typical of the city centre (Salma et al., 2016b). The later event (or events) is mainly caused and governed by subregional processes. These findings are also coherent with a previous observation of NPF and growth events with multiple onsets in semi-clean savannah and industrial environments (Hirsikko et al., 2013), and they also fit well into the existing ideas on mixing regional and urban air parcels that exhibit different properties such as precursor concentrations, $T$ and RH (Kulmala et al., 2017).

\section{Conclusions}

Magnitude of the particle number concentration level produced solely by NPF and growth can roughly be estimated by considering the median $J_{6}$, median duration of nucleation $\Delta t$ (their distribution function is log-normal; Table 2) and the mean coagulation loss of these particles $F_{\text {coag }}(0.17$; Sect. 3.1 and Table S1) as $J_{6} \times \Delta t \times\left(1-F_{\text {coag }}\right)$. In central Budapest, it yields a concentration of $10^{4} \mathrm{~cm}^{-3}$. This is in line with another result achieved using the nucleation strength factor (Salma et al., 2017). More importantly, the estimated concentration is comparable to the annual median atmospheric concentrations (Table 1). This simple example indicates that the phenomenon is relevant not only for aerosol load and climate issues on regional or global spatial scales, which were first recognized. It is sensible also to study the effects of NPF and growth events on urban climate and health risk for inhabitants since they produce a large fraction of particles, even in cities.

Similar recognitions have led urban atmospheric nucleation studies to emerge. As part of this international progress, here we have presented a considerable variety of contributions, which became feasible thanks to gradually generating, multi-year-long, critically evaluated, complex and coherent data sets. Dynamic and timing properties of 247 NPF and growth events were studied together with supporting aerosol properties, meteorological data and pollutant gas concentra- tions in the near-city background and city centre of Budapest for 6 years. The results and conclusions derived form an important component that is based on atmospheric observations. The present study can also be considered the first step toward a larger and more comprehensive statistical evaluation process.

Further dedicated research including sophisticated measurements, data evaluations and modelling studies is required to find and identify additional chemical species and their processes and to account for their multifactorial role in more detail. Such a measurement campaign focusing on chemical composition of molecular clusters, precursors and nucleating vapours by applying recent expedient instruments in Budapest over the months of the highest expected event occurrence has only been realized within a framework of international cooperation. Its prospective results can hopefully provide additional valuable information for some of the conclusion base on indirect evidence for the time being and can further clarify the overall picture on the urban multicomponent nucleation and growth phenomenon.

Data availability. The observational data used in this paper are available on request from the corresponding author or on the website of the Budapest platform for Aerosol Research and Training (http://salma.web.elte.hu/BpArt/, last access: 30 April 2019).

Supplement. The supplement related to this article is available online at: https://doi.org/10.5194/acp-19-5835-2019-supplement.

Author contributions. IS designed the study, performed most data analysis, interpreted the results and wrote the paper. ZN performed most measurements and data treatment and contributed to the data analysis.

Competing interests. The authors declare that they have no conflict of interest.

Acknowledgements. The authors thank Markku Kulmala and his research team at the University of Helsinki for their cooperation. Financial support by the National Research, Development and Innovation Office, Hungary (contracts K116788 and PD124283), and by the European Regional Development Fund and the Hungarian Government (GINOP-2.3.2-15-2016-00028) is gratefully acknowledged.

Review statement. This paper was edited by Xavier Querol and reviewed by six anonymous referees. 


\section{References}

Alam, A., Shi, J. P., and Harrison, R. M.: Observations of new particle formation in urban air, J. Geophys. Res., 108, 4093, https://doi.org/10.1029/2001JD001417, 2003.

Almeida, J., Schobesberger, S., Kurten, A., Ortega, I. K., Kupiainen-Maatta, O., Praplan, A. P., Adamov, A., Amorim, A., Bianchi, F., Breitenlechner, M., David, A., Dommen, J., Donahue, N. M., Downard, A., Dunne, E., Duplissy, J., Ehrhart, S., Flagan, R. C., Franchin, A., Guida, R., Hakala, J., Hansel, A., Heinritzi, M., Henschel, H., Jokinen, T., Junninen, H., Kajos, M., Kangasluoma, J., Keskinen, H., Kupc, A., Kurten, T., Kvashin, A. N., Laaksonen, A., Lehtipalo, K., Leiminger, M., Leppa, J., Loukonen, V., Makhmutov, V., Mathot, S., McGrath, M. J., Nieminen, T., Olenius, T., Onnela, A., Petäjä, T., Riccobono, F., Riipinen, I., Rissanen, M., Rondo, L., Ruuskanen, T., Santos, F. D., Sarnela, N., Schallhart, S., Schnitzhofer, R., Seinfeld, J. H., Simon, M., Sipilä, M., Stozhkov, Y., Stratmann, F., Tome, A., Tröstl, J., Tsagkogeorgas, G., Vaattovaara, P., Viisanen, Y., Virtanen, A., Vrtala, A., Wagner, P. E., Weingartner, E., Wex, H., Williamson, C., Wimmer, D., Ye, P. L., Yli-Juuti, T., Carslaw, K. S., Kulmala, M., Curtius, J., Baltensperger, U., Worsnop, D. R., Vehkamäki, H., and Kirkby, J.: Molecular understanding of sulphuric acid-amine particle nucleation in the atmosphere, Nature, 502, 359-363, 2013.

Baltensperger, U., Streit, N., Weingartner, E., Nyeki, S., Prévôt, A. S. H., Van Dingenen, R., Virkkula, A., Putaud, J. P., Even, A., Brink, H., Blatter, A., Neftel, A., and Gaggeler, H. W.: Urban and rural aerosol characterization of summer smog events during the PIPAPO field campaign in Milan, Italy, J. Geophys. Res., 107, 8193, https://doi.org/10.1029/2001JD001292, 2002.

Bianchi, F., Tröstl, J., Junninen, H., Frege, C., Henne, S., Hoyle, C. R., Molteni, U., Herrmann, E., Adamov, A., Bukowiecki, N., Chen, X., Duplissy, J., Gysel, M., Hutterli, M. Kangasluoma, J., Kontkanen, J., Kürten, A. Manninen, H. E., Münch, S., Peräkylä, O., Petäjä, T., Rondo, L., Williamson, C., Weingartner, E. Curtius, J., Worsnop, D. R., Kulmala, M., Dommen, J., and Baltensperger, U.: New particle formation in the free troposphere: A question of chemistry and timing, Science, 352, 1109-1112, https://doi.org/10.1126/science.aad5456, 2016.

Braakhuis, H. M., Park, M. V., Gosens, I., De Jong, W. H., and Cassee, F. R.: Physicochemical characteristics of nanomaterials that affect pulmonary inflammation, Part. Fibre Toxicol., 11, 18, https://doi.org/10.1186/1743-8977-11-18, 2014.

Cai, R. and Jiang, J.: A new balance formula to estimate new particle formation rate: reevaluating the effect of coagulation scavenging, Atmos. Chem. Phys., 17, 12659-12675, https://doi.org/10.5194/acp-17-12659-2017, 2017.

Carslaw, K. S., Lee, L. A., Reddington, C. L., Pringle, K. J., Rap, A., Forster, P. M., Mann, G. W., Spracklen, D. V., Woodhouse, M. T., Regayre, L. A., and Pierce, J. R: Large contribution of natural aerosols to uncertainty in indirect forcing, Nature, 503, 67-71, 2013.

Crounse, J. D., Nielsen, L. B., Jørgensen, S., Kjaergaard, H. G., and Wennberg, P. O.: Autoxidation of organic compounds in the atmosphere, J. Phys. Chem. Lett., 4, 3513-3520, 2013.

Dal Maso, M., Kulmala, M., Lehtinen, K. E. J., Mäkelä, J. M., Aalto, P. P., and O'Dowd, C.: Condensation and coagulation sinks and formation of nucleation mode particles in coastal and boreal forest boundary layers, J. Geophys. Res., 107, 8097, https://doi.org/10.1029/2001jd001053, 2002.

Dal Maso, M., Kulmala, M., Riipinen, I., Wagner, R., Hussein, T., Aalto, P. P., and Lehtinen, K. E. J.: Formation and growth of fresh atmospheric aerosols: eight years of aerosol size distribution data from SMEAR II, Hyytiälä, Finland, Boreal Environ. Res., 10, 323-336, 2005.

Dall'Osto, M., Querol, X., Alastuey, A., O’Dowd, C., Harrison, R. M., Wenger, J., and Gómez-Moreno, F. J.: On the spatial distribution and evolution of ultrafine particles in Barcelona, Atmos. Chem. Phys., 13, 741-759, https://doi.org/10.5194/acp-13-7412013, 2013.

Ehn, M., Thornton, J. A., Kleist, E., Sipilä, M., Junninen, H., Pullinen, I., Springer, M., Rubach, F., Tillmann, R., Lee, B., LopezHilfiker, F., Andres, S., Acir, I. H., Rissanen, M., Jokinen, T., Schobesberger, S., Kangasluoma, J., Kontkanen, J., Nieminen, T., Kurten, T., Nielsen, L. B., Jorgensen, S., Kjaergaard, H. G., Canagaratna, M., Dal Maso, M., Berndt, T., Petäjä, T., Wahner, A., Kerminen, V. M., Kulmala, M., Worsnop, D. R., Wildt, J., and Mentel, T. F.: A large source of low-volatility secondary organic aerosol, Nature, 506, 476-479, 2014.

Gordon, H., Sengupta, K., Rap, A., Duplissy, J., Frege, C., Williamson, C., Heinritzi, M., Simon, M., Yan, C., Almeida, J., Tröstl, J., Nieminen, T., Ortega, I. K., Wagner, R., Dunne, E. M., Adamov, A., Amorim, A., Bernhammer, A. K., Bianchi, F., Breitenlechner, M., Brilke, S., Chen, X., Craven, J. S., Dias, A., Ehrhart, S., Fischer, L., Flagan, R. C., Franchin, A., Fuchs, C., Guida, R., Hakala, J., Hoyle, C. R., Jokinen, T., Junninen, H., Kangasluoma, J., Kim, J., Kirkby, J., Krapf, M., Kürten, A., Laaksonen, A., Lehtipalo, K., Makhmutov, V., Mathot, S., Molteni, U., Monks, S. A., Onnela, A., Peräkylä, O., Piel, F., Petäjä, T., Praplan, A. P., Pringle, K. J., Richards, N. A. D., Rissanen, M. P., Rondo, L., Sarnela, N., Schobesberger, S., Scott, C. E., Seinfeld, J. H., Sharma, S., Sipilä, M., Steiner, G., Stozhkov, Y., Stratmann, F., Tomé, A., Virtanen, A., Vogel, A. L., Wagner, A. C., Wagner, P. E., Weingartner, E., Wimmer, D., Winkler, P. M., Ye, P., Zhang, X., Hansel, A., Dommen, J., Donahue, N. M., Worsnop, D. R., Baltensperger, U., Kulmala, M., Curtius, J., and Carslaw, K. S.: Reduced anthropogenic aerosol radiative forcing caused by biogenic new particle formation, P. Natl. Acad. Sci. USA, 113, 12053-12058, https://doi.org/10.1073/pnas.1602360113, 2016.

Hamed, A., Korhonen, H., Sihto, S.-L., Joutsensaari, J., Järvinen, H., Petäjä, T., Arnold, F., Nieminen, T., Kulmala, M., Smith, J. N., Lehtinen, K. E. J., and Laaksonen, A.: The role of relative humidity in continental new particle formation, J. Geophys. Res., 116, D03202, https://doi.org/10.1029/2010JD014186, 2011.

Hirsikko, A., Vakkari, V., Tiitta, P., Hatakka, J., Kerminen, V.-M., Sundström, A.-M., Beukes, J. P., Manninen, H. E., Kulmala, M., and Laakso, L.: Multiple daytime nucleation events in semi-clean savannah and industrial environments in South Africa: analysis based on observations, Atmos. Chem. Phys., 13, 5523-5532, https://doi.org/10.5194/acp-13-5523-2013, 2013.

Hussein, T., Puustinen, A., Aalto, P. P., Mäkelä, J. M., Hämeri, K., and Kulmala, M.: Urban aerosol number size distributions, Atmos. Chem. Phys., 4, 391-411, https://doi.org/10.5194/acp-4391-2004, 2004.

Jokinen, T., Berndt, T., Makkonen, R., Kerminen, V.-M., Junninen, H., Paasonen, P., Stratmann, F., Herrmann, H., Guenther, A. B., 
Worsnop, D. R., Kulmala, M., Ehn, M., and Sipilä, M.: Production of extremely low volatile organic compounds from biogenic emissions: Measured yields and atmospheric implications, P. Natl. Acad. Sci. USA, 112, 7123-7128, 2015.

Kerminen, V.-M., Paramonov, M., Anttila, T., Riipinen, I., Fountoukis, C., Korhonen, H., Asmi, E., Laakso, L., Lihavainen, H., Swietlicki, E., Svenningsson, B., Asmi, A., Pandis, S. N., Kulmala, M., and Petäjä, T.: Cloud condensation nuclei production associated with atmospheric nucleation: a synthesis based on existing literature and new results, Atmos. Chem. Phys., 12, 1203712059, https://doi.org/10.5194/acp-12-12037-2012, 2012.

Kerminen, V.-M., Chen, X., Vakkari, V., Petäjä, T., Kulmala, M., and Bianchi, F.: Atmospheric new particle formation and growth: review of field observations, Environ. Res. Lett., 13, 103003, https://doi.org/10.1088/1748-9326/aadf3c, 2018.

Kiendler-Scharr, A., Wildt, J., Dal Maso, M., Hohaus, T., Kleist, E., Mentel, T. F., Tillmann, R., Uerlings, R., Schurr, U., and Wahner, A.: New particle formation in forests inhibited by isoprene emissions, Nature, 461, 381-384, 2009

Kirkby, J., Curtius, J., Almeida, J., Dunne, E., Duplissy, J., Ehrhart, S., Franchin, A., Gagné, S., Ickes, L., Kürten, A., Kupc, A., Metzger, A., Riccobono, F., Rondo, L., Schobesberger, S., Tsagkogeorgas, G., Wimmer, D., Amorim, A., Bianchi, F., Breitenlechner, M., David, A., Dommen, J., Downard, A., Ehn, M., Flagan, R. C., Haider, S., Hansel, A., Hauser, D., Jud, W., Junninen, H., Kreissl, F., Kvashin, A., Laaksonen, A., Lehtipalo, K., Lima, J., Lovejoy, E. R., Makhutov, V., Mathot, S., Mikkilä, J., Minginette, P., Mogo, S., Nieminen, T., Onnela, A., Pereira, A., Petäjä, T., Schnitzhofer, R., Seinfeld, J. H., Sipilä, M., Stozhkov, Y., Stratmann, F., Tome, A., Vanhanen, J., Viisanen, Y., Vrtala, A., Wagner, P. E., Walther, H., Weingartner, E., Wex, H., Winkler, P. M., Carslaw, K. S., Worsnop, D. R., Baltensperger, U., and Kulmala, M.: The role of sulfuric acid, ammonia and galactic cosmic rays in atmospheric aerosol nucleation, Nature, 476, 429-433, 2011.

Kirkby, J., Duplissy, J., Sengupta, K., Frege, C., Gordon, H., Williamson, C., Heinritzi, M., Simon, M., Yan, C., Almeida, J., Tröstl, J., Nieminen, T., Ortega, I. K., Wagner, R., Adamov, A., Amorim, A., Bernhammer, A.-K., Bianchi, F., Breitenlechner, M., Brilke, S., Chen, X., Craven, J., Dias, A., Ehrhart, S., Flagan, R. C., Franchin, A., Fuchs, C., Guida, R., Hakala, J., Hoyle, C. R., Jokinen, T., Junninen, H., Kangasluoma, J., Kim, J., Krapf, M., Kürten, A., Laaksonen, A., Lehtipalo, K., Makhmutov, V., Mathot, S., Molteni, U., Onnela, A., Peräkylä, O., Piel, F., Petäjä, T., Praplan, A. P., Pringle, K., Rap, A., Richards, N. A. D., Riipinen, I., Rissanen, M. P., Rondo, L., Sarnela, N., Schobesberger, S., Scott, C. E., Seinfeld, J. H., Sipilä, M., Steiner, G., Stozhkov, Y., Stratmann, F., Tomé, A., Virtanen, A., Vogel, A. L., Wagner, A., Wagner, P. E., Weingartner, E., Wimmer, D., Winkler, P. M., Ye, P., Zhang, X., Hansel, A., Dommen, J., Donahue, N. M., Worsnop, D. R., Baltensperger, U., Kulmala, M., Carslaw, K. S., and Curtius, J.: Ion-induced nucleation of pure biogenic particles, Nature, 533, 521-526, https://doi.org/10.1038/nature17953, 2016.

Kulmala, M., Dal Maso, M., Mäkelä, J. M., Pirjola, L., Väkevä, M., Aalto, P., Miikkulainen, P., Hämeri, K., and O'Dowd, C. D.: On the formation, growth and composition of nucleation mode particles, Tellus B, 53, 479-490, 2001.

Kulmala, M., Vehkamäki, H., Petäjä, T., Dal Maso, M., Lauri, A., Kerminen, V.-M., Birmili, W., and McMurry, P.: Formation and growth rates of ultrafine atmospheric particles: a review of observations, J. Aerosol Sci., 35, 143-176, 2004.

Kulmala, M., Petäjä, T., Nieminen, T., Sipilä, M., Manninen, H. E., Lehtipalo, K., Dal Maso, M., Aalto, P. P., Junninen, H., Paasonen, P., Riipinen, I., Lehtinen, K. E. J., Laaksonen, A., and Kerminen, V.-M.: Measurement of the nucleation of atmospheric aerosol particles, Nat. Protoc., 7, 1651-1667, https://doi.org/10.1038/nprot.2012.091, 2012.

Kulmala, M., Kontkanen, J., Junninen, H., Lehtipalo, K., Manninen, H. E., Nieminen, T., Petäjä, T., Sipilä, M., Schobesberger, S., Rantala, P., Franchin, A., Jokinen, T., Järvinen, E., Äijälä, M., Kangasluoma, J., Hakala, J., Aalto, P. P., Paasonen, P., Mikkilä, J., Vanhanen, J., Aalto, J., Hakola, H., Makkonen, U., Ruuskanen, T., Mauldin III, R. L., Duplissy, J., Vehkamäki, H., Bäck, J., Kortelainen, A., Riipinen, I., Kurtén, T., Johnston, M. V., Smith, J. N., Ehn, M., Mentel, T. F., Lehtinen, K. E. J., Laaksonen, A., Kerminen, V.-M., and Worsnop, D. R.: Direct observations of atmospheric aerosol nucleation, Science, 339, 943-946, 2013.

Kulmala, M., Petäjä, T., Ehn, M., Thornton, J., Sipilä, M., Worsnop, D. R., and Kerminen, V.-M.: Chemistry of atmospheric nucleation: On the recent advances on precursor characterization and atmospheric cluster composition in connection with atmospheric new particle formation, Annu. Rev. Phys. Chem., 65, 21-37, 2014.

Kulmala, M., Kerminen, V. M., Petäjä, T., Ding, A. J., and Wang, L.: Atmospheric gas-to-particle conversion: why NPF events are observed in megacities, Faraday Discuss., 200, 271-288, https://doi.org/10.1039/C6FD00257A, 2017.

Makkonen, R., Asmi, A., Korhonen, H., Kokkola, H., Järvenoja, S., Räisänen, P., Lehtinen, K. E. J., Laaksonen, A., Kerminen, V.M., Järvinen, H., Lohmann, U., Bennartz, R., Feichter, J., and Kulmala, M.: Sensitivity of aerosol concentrations and cloud properties to nucleation and secondary organic distribution in ECHAM5-HAM global circulation model, Atmos. Chem. Phys. 9, 1747-1766, https://doi.org/10.5194/acp-9-1747-2009, 2009.

Makkonen, R., Asmi, A., Kerminen, V.-M., Boy, M., Arneth, A., Hari, P., and Kulmala, M.: Air pollution control and decreasing new particle formation lead to strong climate warming, Atmos. Chem. Phys., 12, 1515-1524, https://doi.org/10.5194/acp12-1515-2012, 2012.

Merikanto, J., Spracklen, D. V., Mann, G. W., Pickering, S. J., and Carslaw, K. S.: Impact of nucleation on global CCN, Atmos. Chem. Phys., 9, 8601-8616, https://doi.org/10.5194/acp-9-86012009, 2009.

Metzger, A., Verheggen, B., Dommen, J., Duplissy, J., Prévôt, A. S. H., Weingartner, E., Riipinen, I., Kulmala, M., Spracklen, D. V., Carslaw, K. S., and Baltensperger, U.: Evidence for the role of organics in aerosol particle formation under atmospheric conditions, P. Natl. Acad. Sci. USA, 107, 6646-6651, 2010.

Németh, Z. and Salma, I.: Spatial extension of nucleating air masses in the Carpathian Basin, Atmos. Chem. Phys., 14, 8841-8848, https://doi.org/10.5194/acp-14-8841-2014, 2014.

Németh, Z., Rosati, B., Zíková, N., Salma, I., Bozó, L., Dameto de España, C., Schwarz, J., Ždímal, V., and Wonaschütz, A.: Comparison of atmospheric new particle formation and growth events in three Central European cities, Atmos. Environ., 178, 191-197, 2018.

Nieminen, T., Kerminen, V.-M., Petäjä, T., Aalto, P. P., Arshinov, M., Asmi, E., Baltensperger, U., Beddows, D. C. S., Beukes, J. 
P., Collins, D., Ding, A., Harrison, R. M., Henzing, B., Hooda, R., Hu, M., Hõrrak, U., Kivekäs, N., Komsaare, K., Krejci, R., Kristensson, A., Laakso, L., Laaksonen, A., Leaitch, W. R., Lihavainen, H., Mihalopoulos, N., Németh, Z., Nie, W., O’Dowd, C., Salma, I., Sellegri, K., Svenningsson, B., Swietlicki, E., Tunved, P., Ulevicius, V., Vakkari, V., Vana, M., Wiedensohler, A., Wu, Z., Virtanen, A., and Kulmala, M.: Global analysis of continental boundary layer new particle formation based on longterm measurements, Atmos. Chem. Phys., 18, 14737-14756, https://doi.org/10.5194/acp-18-14737-2018, 2018.

Oberdörster, G., Oberdörster, E., and Oberdörster, J.: Nanotoxicology: an emerging discipline evolving from studies of ultrafine particles, Environ. Health Perspect., 113, 823-839, 2005.

O’Dowd, C. D., Jimenez, J. L., Bahreini, R., Flagan, R. C., Seinfeld, J. H., Hämeri, K., Pirjola, L., Kulmala, M., Jennings, S. G., and Hoffmann, T: Marine aerosol formation from biogenic iodine emissions, Nature, 417, 632-636, 2002.

Paasonen, P., Kupiainen, K., Klimont, Z., Visschedijk, A., Denier van der Gon, H. A. C., and Amann, M.: Continental anthropogenic primary particle number emissions, Atmos. Chem. Phys., 16, 6823-6840, https://doi.org/10.5194/acp-166823-2016, 2016.

Paasonen, P., Peltola, M., Kontkanen, J., Junninen, H., Kerminen, V.-M., and Kulmala, M.: Comprehensive analysis of particle growth rates from nucleation mode to cloud condensation nuclei in boreal forest, Atmos. Chem. Phys., 18, 12085-12103, https://doi.org/10.5194/acp-18-12085-2018, 2018.

Petäjä, T., Mauldin III, R. L., Kosciuch, E., McGrath, J., Nieminen, T., Paasonen, P., Boy, M., Adamov, A., Kotiaho, T., and Kulmala, M.: Sulfuric acid and $\mathrm{OH}$ concentrations in a boreal forest site, Atmos. Chem. Phys., 9, 7435-7448, https://doi.org/10.5194/acp9-7435-2009, 2009.

Putaud, J.-P., Van Dingenen, R., Alastuey, A., Bauer, H., Birmili, W., Cyrys, J., Flentje, H., Fuzzi, S., Gehrig, R., Hansson, H. C., Harrison, R. M., Herrmann, H., Hitzenberger, R., Hüglin, C., Jones, A.M., Kasper-Giebl, A., Kiss, G., Kousa, A., Kuhlbusch, T. A. J., Löschau, G., Maenhaut, W., Molnár, A., Moreno, T., Pekkanen, J., Perrino, C., Pitz, M., Puxbaum, H., Querol, X., Rodriguez, S., Salma, I., Schwarz, J., Smolík, J., Schneider, J., Spindler, G., ten Brink, H., Turšič, J., Viana, M., Wiedensohler, A., and Raes, F.: A European Aerosol Phenomenology - 3: physical and chemical characteristics of particulate matter from 60 rural, urban, and kerbside sites across Europe, Atmos. Environ., 44, 1308-1320, 2010.

Riccobono, F., Schobesberger, S., Scott, C., Dommen, J., Ortega, I., Rondo, L., Almeida, J., Amorim, A., Bianchi, F., Breitenlechner, M., David, A., Downard, A., Dunne, E., Duplissy, J., Ehrhart, S., Flagan, R., Franchin, A., Hansel, A., Junninen, H., Kajos, M., Keskinen, H., Kupc, A., Kurten, A., Kvashin, A., Laaksonen, A., Lehtipalo, K., Makhmutov, V., Mathot, S., Nieminen, T., Onnela, A., Petäjä, T., Praplan, A., Santos, F., Schallhart, S., Seinfeld, J., Sipila, M., Spracklen, D., Stozhkov, Y., Stratmann, F., Tome, A., Tsagkogeorgas, G., Vaattovaara, P., Viisanen, Y., Vrtala, A., Wagner, P., Weingartner, E., Wex, H., Wimmer, D., Carslaw, K., Curtius, J., Donahue, N., Kirkby, J., Kulmala, M., Worsnop, D., and Baltensperger, U.: Oxidation products of biogenic emissions contribute to nucleation of atmospheric particles, Science, 344, 717-721, 2014.
Riipinen, I., Pierce, J. R., Yli-Juuti, T., Nieminen, T., Häkkinen, S., Ehn, M., Junninen, H., Lehtipalo, K., Petäjä, T., Slowik, J., Chang, R., Shantz, N. C., Abbatt, J., Leaitch, W. R., Kerminen, V.-M., Worsnop, D. R., Pandis, S. N., Donahue, N. M., and Kulmala, M.: Organic condensation: a vital link connecting aerosol formation to cloud condensation nuclei (CCN) concentrations, Atmos. Chem. Phys., 11, 3865-3878, https://doi.org/10.5194/acp-11-3865-2011, 2011.

Salma, I., Borsós, T., Weidinger, T., Aalto, P., Hussein, T., Dal Maso, M., and Kulmala, M.: Production, growth and properties of ultrafine atmospheric aerosol particles in an urban environment, Atmos. Chem. Phys., 11, 1339-1353, https://doi.org/10.5194/acp-11-1339-2011, 2011.

Salma, I., Borsós, T., Németh, Z., Weidinger, T., Aalto, T., and Kulmala, M.: Comparative study of ultrafine atmospheric aerosol within a city, Atmos. Environ., 92, 154-161, 2014.

Salma, I., Füri, P., Németh, Z., Farkas, Á., Balásházy, I., Hofmann, W., and Farkas, Á.: Lung burden and deposition distribution of inhaled atmospheric urban ultrafine particles as the first step in their health risk assessment, Atmos. Environ., 104, 39-49, 2015.

Salma, I., Németh, Z., Weidinger, T., Kovács, B., and Kristóf, G.: Measurement, growth types and shrinkage of newly formed aerosol particles at an urban research platform, Atmos. Chem. Phys., 16, 7837-7851, https://doi.org/10.5194/acp16-7837-2016, 2016a.

Salma, I., Németh, Z., Kerminen, V.-M., Aalto, P., Nieminen, T., Weidinger, T., Molnár, Á., Imre, K., and Kulmala, M.: Regional effect on urban atmospheric nucleation, Atmos. Chem. Phys., 16, 8715-8728, https://doi.org/10.5194/acp-16-8715-2016, 2016b.

Salma, I., Varga, V., and Németh, Z.: Quantification of an atmospheric nucleation and growth process as a single source of aerosol particles in a city, Atmos. Chem. Phys., 17, 1500715017, https://doi.org/10.5194/acp-17-15007-2017, 2017.

Schobesberger, S., Junninen, H., Bianchi, F., Lonn, G., Ehn, M., Lehtipalo, K., Dommen, J., Ehrhart, S., Ortega, I. K., Franchin, A., Nieminen, T., Riccobono, F., Hutterli, M., Duplissy, J., Almeida, J., Amorim, A., Breitenlechner, M., Downard, A. J., Dunne, E. M., Flagan, R. C., Kajos, M., Keskinen, H., Kirkby, J., Kupc, A., Kurten, A., Kurten, T., Laaksonen, A., Mathot, S., Onnela, A., Praplan, A. P., Rondo, L., Santos, F. D., Schallhart, S., Schnitzhofer, R., Sipilä, M., Tome, A., Tsagkogeorgas, G., Vehkamäki, H., Wimmer, D., Baltensperger, U., Carslaw, K. S., Curtius, J., Hansel, A., Petäjä, T., Kulmala, M., Donahue, N. M., and Worsnop, D. R.: Molecular understanding of atmospheric particle formation from sulfuric acid and large oxidized organic molecules, P. Natl. Acad. Sci. USA., 110, 17223-17228, https://doi.org/10.1073/pnas.1306973110, 2013.

Sihto, S.-L., Mikkilä, J., Vanhanen, J., Ehn, M., Liao, L., Lehtipalo, K., Aalto, P. P., Duplissy, J., Petäjä, T., Kerminen, V.-M., Boy, M., and Kulmala, M.: Seasonal variation of CCN concentrations and aerosol activation properties in boreal forest, Atmos. Chem. Phys., 11, 13269-13285, https://doi.org/10.5194/acp-11-132692011, 2011.

Sipilä, M., Berndt, T., Petäjä, T., Brus, D., Vanhanen, J., Stratmann, F., Patokoski, J., Mauldin III, R. L., Hyvärinen, A. P., Lihavainen, H., and Kulmala, M.: The role of sulfuric acid in atmospheric nucleation, Science, 327, 1243-1246, https://doi.org/10.1126/science.1180315, 2010. 
Spracklen, D. V., Carslaw, K. S., Kulmala, M., Kerminen, V.-M., Mann, G. W., and Sihto, S.-L.: The contribution of boundary layer nucleation events to total particle concentrations on regional and global scales, Atmos. Chem. Phys., 6, 5631-5648, https://doi.org/10.5194/acp-6-5631-2006, 2006.

Sun, J., Birmili, W., Hermann, M., Tuch, T., Weinhold, K., Spindler, G., Schladitz, A., Bastian, S., Löschau, G., Cyrys, J., Gu, J., Flentje, H., Briel, B., Asbach, C., Kaminski, H., Ries, L., Sohmer, R., Gerwig, H., Wirtz, K., Meinhardt, F., Schwerin, A., Bath, O., Ma, N., and Wiedensohler, A.: Variability of Black Carbon mass concentrations, sub-micrometer particle number concentrations and size distributions: Results of the German Ultrafine Aerosol Network ranging from city street to high Alpine locations, Atmos. Environ., 202, 256-268, 2019.

Tröstl, J., Chuang, W. K., Gordon, H., Heinritzi, M., Yan, C., Molteni, U., Ahlm, L., Frege, C., Bianchi, F., Wagner, R., Simon, M., Lehtipalo, K., Williamson, C., Craven, J. S., Duplissy, J., Adamov, A., Almeida, J., Bernhammer, A. K., Breitenlechner, M., Brilke, S., Dias, A., Ehrhart, S., Flagan, R. C., Franchin, A., Fuchs, C., Guida, R., Gysel, M., Hansel, A., Hoyle, C. R., Jokinen, T., Junninen, H., Kangasluoma, J., Keskinen, H., Kim, J., Krapf, M., Kürten, A., Laaksonen, A., Lawler, M., Leiminger, M., Mathot, S., Möhler, O., Nieminen, T., Onnela, A., Petäjä, T., Piel, F. M., Miettinen, P., Rissanen, M. P., Rondo, L., Sarnela, N., Schobesberger, S., Sengupta, K., Sipilä, M., Smith, J. N., Steiner, G., Tomè, A., Virtanen, A., Wagner, A. C., Weingartner, E., Wimmer, D., Winkler, P. M., Ye, P. L., Carslaw, K. S., Curtius, J., Dommen, J., Kirkby, J., Kulmala, M., Riipinen, I., Worsnop, D. R., Donahue, N. M., and Baltensperger, U.: The role of low-volatility organic compounds in initial particle growth in the atmosphere, Nature, 533, 527-531, https://doi.org/10.1038/nature18271, 2016.

Vakkari, V., Tiitta, P., Jaars, K., Croteau, P., Beukes, J. P., Josipovic, M., Kerminen, V.-M., Kulmala, M., Venter, A. D., van Zyl, P. G., Worsnop, D. R., and Laakso, L.: Reevaluating the contribution of sulfuric acid and the origin of organic compounds in atmospheric nanoparticle growth, Geophys. Res. Lett., 42, 1048610493, 2015.

Vuollekoski, H., Sihto, S.-L., Kerminen, V.-M., Kulmala, M., and Lehtinen, K. E. J.: A numerical comparison of different methods for determining the particle formation rate, Atmos. Chem. Phys., 12, 2289-2295, https://doi.org/10.5194/acp12-2289-2012, 2012.
Wehner, B., Wiedensohler, A., Tuch, T. M., Wu, Z. J., Hu, M., Slanina, J., and Kiang, C. S.: Variability of the aerosol number size distribution in Beijing, China: new particle formation, dust storms, and high continental background, Geophys. Res. Lett., 31, L22108, https://doi.org/10.1029/2004GL021596, 2004.

Wiedensohler, A., Birmili, W., Nowak, A., Sonntag, A., Weinhold, K., Merkel, M., Wehner, B., Tuch, T., Pfeifer, S., Fiebig, M., Fjäraa, A. M., Asmi, E., Sellegri, K., Depuy, R., Venzac, H., Villani, P., Laj, P., Aalto, P., Ogren, J. A., Swietlicki, E., Williams, P., Roldin, P., Quincey, P., Hüglin, C., Fierz-Schmidhauser, R., Gysel, M., Weingartner, E., Riccobono, F., Santos, S., Grüning, C., Faloon, K., Beddows, D., Harrison, R., Monahan, C., Jennings, S. G., O’Dowd, C. D., Marinoni, A., Horn, H.-G., Keck, L., Jiang, J., Scheckman, J., McMurry, P. H., Deng, Z., Zhao, C. S., Moerman, M., Henzing, B., de Leeuw, G., Löschau, G., and Bastian, S.: Mobility particle size spectrometers: harmonization of technical standards and data structure to facilitate high quality long-term observations of atmospheric particle number size distributions, Atmos. Meas. Tech., 5, 657-685, https://doi.org/10.5194/amt-5-657-2012, 2012.

Woo, K. S., Chen, D. R., Pui, D. Y. H., and McMurry, P. H.: Measurement of Atlanta aerosol size distributions: observations of ultrafine particle events, Aerosol Sci. Technol., 34, 75-87, 2001.

Xiao, S., Wang, M. Y., Yao, L., Kulmala, M., Zhou, B., Yang, X., Chen, J. M., Wang, D. F., Fu, Q. Y., Worsnop, D. R., and Wang, L.: Strong atmospheric new particle formation in winter in urban Shanghai, China, Atmos. Chem. Phys., 15, 1769-1781, https://doi.org/10.5194/acp-15-1769-2015, 2015.

Yli-Juuti, T., Riipinen, I., Aalto, P. P., Nieminen, T., Maenhaut, W., Janssens, I. A., Claeys, M., Salma, I., Ocskay, R., Hoffer, A., Imre, K., and Kulmala, M.: Characteristics of new particle formation events and cluster ions at K-puszta, Hungary, Boreal Environ. Res., 14, 683-698, 2009.

Zhang, R., Wang, G., Guo, S., Zamora, M. L., Ying, Q., Lin, Y., Wang, W., Hu, M., and Wang, Y.: Formation of urban fine particulate matter, Chem. Rev., 115, 3803-3855, 2015. 